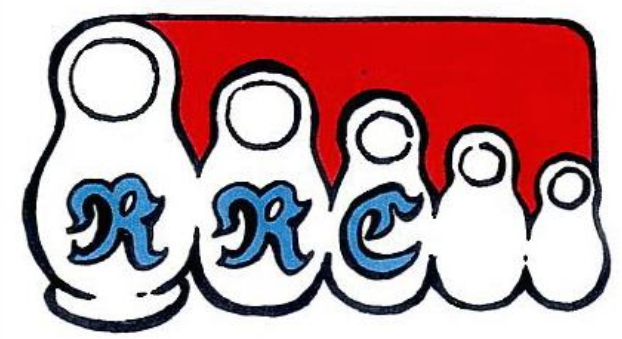

RRC Working Paperйских Исследований

\title{
Distressed Acquisitions Evidence from European Emerging Markets
}

\author{
Ichiro Iwasaki, Evžen Kočenda, \\ and Yoshisada Shida
}

April 2021

\author{
RUSSIAN RESEARCH CENTER \\ THE INSTITUTE OF ECONOMIC RESEARCH \\ HITOTSUBASHI UNIVERSITY \\ Kunitachi, Tokyo, JAPAN
}


RRC Working Paper No. 90

April 2021

\title{
Distressed Acquisitions Evidence from European Emerging Markets*
}

\author{
Ichiro Iwasaki, ${ }^{a}$ Evžen Kočenda,${ }^{b}$ and Yoshisada Shida ${ }^{c}$
}

\begin{abstract}
We analyze factors behind 23,213 distressed acquisitions in European emerging markets from 2007-2019. Besides the impact of financial ratios, legal form, ownership structure, firm size, and age, we emphasize the role of institutions and channels of their propagation. We show that the quality and enforcement of insolvency laws are linked with the lower probability of distressed acquisitions, followed by corruption control and progress in banking reforms. The impact of institutions is larger in lessadvanced countries as compared to economically stronger ones. The effect of institutions increased after the financial crisis but declined as the economic situation improved.
\end{abstract}

Keywords: distressed acquisitions, mergers, European emerging markets

JEL Classifications: C35, D02, D22, E02, G34, K20, L22

\footnotetext{
* We would like to thank Ruben Enikolopov, Bartosz Kabaciński, Piotr Kozarzewski, Petr Marek, Satoshi Mizobata, Holger Mueller, and participants at several presentations for their helpful comments and suggestions. Kočenda acknowledges the hospitality of the Kyoto Institute of Economic Research. We are also grateful to Eriko Yoshida for her research assistance and to Tammy Bicket for her editorial assistance. This research was financially supported by the Japan Society for the Promotion of Science (Grant Nos. 19KK0036 and 20H01489), the Japan Securities Scholarship Foundation, the Nomura Foundation, the Mitsubishi Foundation, and the Joint Usage and Research Center of the Institute of Economic Research, Hitotsubashi University (Iwasaki); and the Slovak Research and Development Agency (Grant No. APVV-18-0310) (Kočenda). The usual disclaimer applies.

${ }^{a}$ Institute of Economic Research, Hitotsubashi University, Naka 2-1, Kunitachi, Tokyo 186-8603, Japan; E-mail: iiwasaki@ier.hit-u.ac.jp (corresponding author)

${ }^{\mathrm{b}}$ Institute of Economic Studies, Faculty of Social Sciences, Charles University, Opletalova 26, 110 00, Prague, Czech Republic; CESifo, Munich; IOS, Regensburg; E-mail: evzen.kocenda@fsv.cuni.cz ${ }^{\mathrm{c}}$ Economic Research Institute for Northeast Asia (ERINA), Bandaijima 5-1, Chuo-ku, Niigata 950-0078, Japan; E-mail: shida.yoshisada.2@erina.or.jp
} 


\section{Introduction, motivation and related literature}

Acquisitions of firms under financial distress, namely distressed acquisitions, represent both challenges as well as significant opportunities for acquirers, and knowing what factors impact distressed acquisitions offers crucial and valuable insights (DePamphilis, 2019). However, research on determinants behind distressed acquisitions is quite limited and, in terms of the regional coverage, the literature mostly targets firms in developed countries. Evidence from emerging markets lags behind, and the coverage of European emerging economies is virtually nonexistent. This is surprising, given the substantial economic potential of these countries (Darvas, 2011; Cubeddu et al., 2014) and the persuasive evidence showing that standard acquisitions of firms in emerging markets deliver positive and significant abnormal returns to acquirers from developed countries, who benefit from differences in the quality of institutions (Chari et al., 2010). In this paper, we analyze financial, firm-specific, and especially (i) institutional factors and their impact on failure and the acquisition of distressed firms, (ii) while concentrating on under-researched emerging economies in Europe. The accent on both issues is motivated by the following reasons.

First, our emphasis on the role of institutions is grounded in assessing a causal link with respect to acquisitions. The nexus between institutions and acquisitions is underlined primarily by the quality of the legal environment in general. More specifically, disparities in institutional background are identified behind the diversity in bankruptcy laws across countries (Claessens and Klapper, 2005). With respect to the distress, Claessens et al. (2001) argue that the quality of bankruptcy laws affects resolution of financial distress. Acharya et al. (2011) provide a theoretical model to show that differences in bankruptcy codes affect the anticipated liquidation value of a firm's assets, which is again a direct outcome of the distress resolution. Other areas of law are important for acquisitions as well, since both strong creditor and shareholder rights increase the use of bankruptcy, relative to acquisitions, as a mechanism for resolving financial distress (Dahiya and Klapper, 2007). In this respect, the institutional impact has been brought forth previously by La Porta et al. $(1998,2013)$, who emphasized the importance of legal rules covering the protection of corporate creditors and their enforcement. We elaborate more on a theoretical framework related to the role of institutions in Section 2.3. In terms of empirical evidence, the importance of the quality of institutions with respect to acquisitions in emerging markets is shown by Claessens et al. (2001), Meyer et al. (2009), Chari et al. (2010), Fan et al. (2013), and Lebedev et al. (2015).

Second, entry into emerging markets via mergers and acquisitions represents a relatively 
new phenomenon because, until the early 1990s, emerging economies frequently imposed restrictions on foreign acquirers (Evenett, 2004). Since then, a substantial wave of mergers and acquisitions (initiated by firms from developed countries) dramatically raised the foreign economic participation in Latin America and East Asia in connection with privatizations and the lifting of bans on foreign corporate control (Mody and Negishi, 2001; De Paula et al., 2002). In Europe, in the early 1990s, multinational firms from developed economies launched numerous acquisitions in connection with massive privatizations of state-owned companies during the economic transformation of Central and Eastern European (CEE) countries (Estrin et al., 2009; Meyer et al., 2009; Iwasaki and Mizobata, 2018). Recently, the global financial crisis (GFC) has hit hard CEE companies (Hanousek et al., 2015), leading many of them into financial distress and forcing some to exit the market (Baumöhl et al., 2019; Iwasaki and Kim, 2020; Iwasaki et al., 2021). Under these circumstances, takeovers by stronger counterparts represent a viable solution for restructuring the assets of distressed firms, as a takeover may serve as an emergency-resolution mechanism instead of bankruptcy (Stiglitz, 1972). In the subsequent account, we further detail our motivation.

Firms that experience economic or financial distress need to pass through a successful turnaround via a category of restructuring (Schweizer and Nienhaus, 2017). ${ }^{1}$ One specific type of restructuring of a distressed firm is the merger of its operations with those of an acquirer (Clark and Ofek, 1994). Despite the fact that acquisitions, as a form of takeover and organizational restructuring, have long been employed as a tool for resolving financial distress (Nesvold et al., 2010), they still offer ample room for research. ${ }^{2}$ In addition, while there exists a limited literature body analyzing factors that impact the acquisition of distressed firms in developed countries, the issue remains unexplored with respect to emerging markets.

In their early work, Pastena and Ruland (1986) analyzed a set of variables with respect to their ability to predict the acquisition of distressed US firms. Their results showed a positive link between the probability of distressed acquisition and ownership concentration or firm size, while a negative link to financial leverage was found. Peel and Wilson (1989) assessed a similar

\footnotetext{
${ }^{1}$ Schweizer and Nienhaus (2017) reviewed literature on corporate distress and turnaround, defined as "a decline and recovery from distress." They also covered operational, managerial, portfolio, and financial restructuring.

${ }^{2}$ The terms mergers and acquisitions are often used interchangeably, but in reality, they have somewhat different meanings. A transaction that combines two companies and leads to the creation of a new company is a merger. A purchase of one firm by another firm, which does not lead to the creation of a new firm, is an acquisition. We use the term acquisition, not merger, because business combinations involving distressed firms are not usually mergers of firms on equal (financial) footing.
} 
topic for UK firms, but they found no link between ownership concentration and firm size or acquisition probability. On the contrary, they showed that the choice to acquire a distressed company is primarily rooted in the extent of potential synergies and the severity of financial distress. In a more recent work, Theodossiou et al. (1996; p. 712) improved the testing strategy on a sample of distressed US firms; they showed that "the two most important factors for acquiring a financially distressed firm are the sales-generating ability of the firm's total assets and the presence of inefficient management. Insider control appears to be the third most significant factor providing support to the hypothesis that insiders generally resist an acquisition because of fears of losing their jobs." Additional factors found to have predictive power are the ratio of productive (fixed) assets to total assets, return on fixed assets, and financial leverage. Recent contributions to the literature, for example, those of Åstebro and Winter (2012) and Miglani et al. (2015), assert predictive power for a similar set of variables.

Another strand of the literature on distressed acquisitions investigates differences between pre- and post-acquisition performance. In these studies, stock prices are frequently used as performance measures. In an early work, based on a sample of 55 acquisitions of bankrupt US companies, Hotchkiss and Mooradian (1998) provided empirical evidence that takeovers can facilitate the efficient redeployment of assets of bankrupt firms. Clark and Ofek (1994) analyzed 38 takeovers of distressed US firms and showed that these takeovers are more likely to involve firms in the same industry, are less likely to be hostile takeovers than are acquisitions in general, and that bidders are unable to successfully restructure targets. Bruton et al. (1994) examined 51 acquisitions of financially distressed US firms and found that the best performance was observed in cases when acquirers had prior acquisition experience. Their results imply that implicit knowledge about the acquisition process, integration of the assets of distressed firms, and their management may be key factors for a successful acquisition.

Broader earlier literature on mergers and acquisitions agreed with findings that an acquirer's gains are usually small or close to zero (see Andrade et al. (2001) and Eckbo (2014) for literature reviews). On the other hand, Chari et al. (2010) documented that when foreign owners secure effective control of firms in emerging markets, they realize significant and positive abnormal returns, capitalizing on asymmetry between the quality of institutions in developed and emerging markets. Further, DePamphilis (2019) argued that new evidence in recent literature shows acquirers realizing significant abnormal returns for both cash and stock purchases of public companies since the economic recovery of 2009. Finally, in a recent detailed work aimed at analyzing acquisitions during severe distress, Meier and Servaes (2019) compared fire sales to a sample of regular acquisitions. They showed that acquirers who buy 
assets in fire sales earn excess returns that are two percentage points higher than in regular acquisitions. They demonstrated that the identified effect of the fire sales rests in sellers' reduced bargaining power, and they concluded that the welfare losses associated with fire sales are smaller than previously thought. The assessment of differences between pre- and postacquisition performance is not part of our analysis. Nevertheless, we reviewed some key works above, as the issue is related to our analysis. ${ }^{3}$

In our paper, we do not assess post-acquisition performance, and we do not use stock prices. Instead, we employ granular firm-level data and concentrate on analyzing factors that impact decisions to acquire a distressed firm. In our data, we observe distressed and failing firms that were subsequently incorporated into stronger firms. After their acquisition, distressed firms ceased to exist legally. Consequently, in our analysis, we proceed in two stages that correspond to a Heckman two-stage probit model. Specifically, in the first stage, we estimate the probability of distressed firm failure by employing a set of variables similar to that used by Baumöhl et al. (2019). In the second stage, we employ a probability of acquisition of a distressed firm as our dependent variable and analyze factors behind the distressed acquisition. These factors constitute a set of explanatory variables motivated by Theodossiou et al. (1996), Platt and Platt (2008), and other relevant studies.

Naturally, the emphasis of our analysis lies in estimates from the second stage, where we model the probability of distressed acquisition as a function of specific factors - this is our key question of interest. We distinguish among three sets of factors. First, following Theodossiou et al. (1996), we include a set of financial performance variables. In accordance with the related literature, we hypothesize that better financial performance is linked to less need for distressed acquisition. Second, we account for the potential impact of ownership structures, legal form, firm size, and age that were empirically shown to influence the acquisition process in emerging markets (Fan et al., 2013) as well as in mature markets (Xu, 2019). Third, we account for differences among countries regarding the quality of their institutions and explore their role with respect to acquisitions. Our accent on institutions is motivated by the seminal theoretical work of North (1990), who shows that institutions mediate an incentive structure that is ultimately linked with transaction costs, and of North (1993), who stresses the importance of credible commitment with respect to firm performance. In our analysis, we employ institutional factors covering law enforcement, corruption control, and

\footnotetext{
${ }^{3}$ Understanding the nature of transactions that do create significant shareholder wealth is of natural significance.
} 
financial development. In Section 2.3, we introduce a theoretical framework underpinning the institutional setting in more detail.

For our analysis, we employ a large dataset described in Section 2. The dataset is salient for addressing the impact of institutions because it covers 17 European emerging markets that are characterized by variations in institutional quality and the legal protection of property rights. In any event, in both stages, we model probabilities with sets of theoretically and empirically grounded factors that are germane to the probability consequence; these variables are described in detail in the data section.

We contribute to the literature in several ways. First, we provide evidence of the impact of a number of firm-specific characteristics and financial indicators on distressed acquisitions. Second, we show that better institutions decrease the need for distressed acquisitions. Institutions related to quality and the enforcement of insolvency law are especially effective at lowering the probability of distressed acquisition. The extent of corruption control and progress in banking reform are also strong factors linked to lowering the probability of distressed acquisition. Third, the qualitative impact of broadly defined institutions is similar across European emerging markets, but institutions tend to have a larger impact on distressed acquisitions in less-advanced countries as compared to economically stronger ones. We take this as indirect evidence of the diminishing marginal returns of institutions with respect to their quality. Fourth, the effect of institutions increased after the global financial crisis (GFC), but as the economic situation improves, their impact declines.

The remainder of the paper is organized as follows. In Section 2, we describe the data, variables, and theoretical underpinning with hypothesized impacts. In Section 3, we introduce our empirical strategy. In Section 4, we bring forth extensive and detailed results. Section 5 is the conclusion.

\section{Data coverage, variables, and hypothesized impacts}

With the aim of studying the distressed acquisition of firms and its relationship with countrylevel institutional quality, we employ a large dataset of business firms in European emerging economies. Our dataset consists of financial, firm-specific, and country-level institutional variables. The set of financial and firm-specific variables is extracted from the Bureau van Dijk's Orbis database. ${ }^{4}$ In Figure 1 and Table 1, we present a comprehensive account of the

\footnotetext{
${ }^{4}$ Orbis is one of the largest company databases, covering more than 300 million companies worldwide; as such, it contains a large sample of listed and unlisted companies operating in various industries in
} 
numbers and proportions of firms in our dataset. As both sources show, we are able to clearly identify the survival status of a total of 247,501 firms (N) in 17 European emerging economies from 2007-2019. Of these firms, 23,213 were involved in distressed acquisitions (D).

Firms in our dataset satisfy two conditions: (i) they were in business at the end of 2006 (i.e., before the GFC), and (ii) they provided information about their survival status at the end of 2019. In terms of regional distribution, we cover firms from: (a) Central European countries (Czech Republic, Hungary, Poland, and Slovakia); (b) Eastern European countries (Bosnia and Herzegovina, Bulgaria, Croatia, Macedonia, Montenegro, Romania, and Serbia); (c) Baltic countries (Estonia, Latvia, and Lithuania); and (d) former Soviet Union (FSU) countries (Moldova, Russia, and Ukraine). In terms of economic development, we cover stronger countries that are members of the EU as well as less-advanced economies. ${ }^{5}$

In addition, and quite importantly, in our sample, we also have information regarding each firm's legal status that enables us to identify (i) when and how a company failed and (ii) whether the distressed firm was later merged. Specifically, referring to changes in status registered in the Orbis database, it is possible to categorize each entry firm as either (A) a company that maintained operations through the observed period without management failure (i.e., survivors), (B) a company that was "bankrupted," "liquidated," or "dissolved" without any subsequent legal status change before the end of the observed period, (C) a company that became "dormant" during the observed period, or (D) a company that became "dormant," "bankrupt," "liquidated," or "dissolved" with a subsequent legal status change to "merged/taken over" within the observed period. In this study, firms that fall into category (D) are classified as distressed acquisitions. ${ }^{6}$

According to Figure 1 and Table 1, the key observation is that, during the research period, about $41.1 \%$ of firms failed $(\mathrm{F} / \mathrm{N}$; Table 1$)$. Of these, $22.8 \%$ were acquired in distress (D/F; Table 1). Multiples of the two proportions mean that distressed acquisitions represent more than $9.4 \%$ of firms in our sample. The proportions signal that the vulnerability of firms in

European emerging economies. Appendix A overviews the Orbis database and describes the procedure of compiling our dataset.

${ }^{5}$ The EU members covered in our analysis are (alphabetically): Bulgaria, Croatia, Czech Republic, Estonia, Hungary, Latvia, Lithuania, Poland, Romania, and Slovakia.

${ }^{6} \mathrm{We}$ did not include firms whose status had changed to "merged/taken over" without any notification of management failure in the preceding period in the dataset because these cases may contain "peaceful" M\&As that were not triggered by the financial distress of the acquired company. We believe that this judgment is reasonable because distressed acquisitions tend to take place within one year after the management failure of acquired companies. 
emerging markets is quite high. In Table 1, a more detailed breakdown is provided for firms across country groups and widely defined industry sectors. The share of distressed acquisitions in failed firms is highest in FSU countries (27.7\%), followed by Central European countries (16.1\%), while Eastern European and Baltic countries exhibit a much lower share $(4.6 \%$ and $8.1 \%$, respectively). Across industries, the shares are more level, ranging between 18.8 and $28.5 \%$.

Further, in Figure 2, we show that the wave of distressed acquisitions coincides with post-crisis developments as the rate of distressed acquisitions climbs from 2007-2010 and then recedes, as the potential for viable restructuring via distressed acquisitions diminishes. The negative impact of the European sovereign debt crisis can be conjectured based on a single jump in 2014.

In addition to the detailed classification of firms, the Orbis database also provides data regarding relevant firm characteristics used in the literature related to financial distress. Specifically, we have information regarding each firm's legal form of incorporation, ownership structure, corporate governance structure, financial performance, size, and age. Additional data regarding country-level institutional variables are obtained from the European Bank for Reconstruction and Development (EBRD) and the Freedom House. We provide details in Subsection 2.3.

In the next subsection, we introduce the rationale for each variable included in our models along with its hypothesized impact. Detailed descriptions of the factors analyzed with firm distress and acquisitions are provided in Table 2.

\subsection{Financial indicators}

Financial performance is measured by several representative variables identified in earlier literature as impacting the probability of distress and eventual exit or survival (Baumöhl et al., 2019). The performance variables are also used as factors behind acquisitions (DePamphilis, 2019). Specifically, as shown in Table 2, we employ return on assets (ROA), liquidity, solvency, and labor productivity.

Return on assets (ROA) serves as a proxy for a firm's profitability, and its higher value is associated with a lower probability of financial distress and bankruptcy (Görg and Spaliara, 2014), thus, producing a negative impact on the likelihood of distress (bankruptcy). On the other hand, "financially distressed firms with above average profitability may be appealing acquisition targets to firms that have means and know how to alleviate their financial distress 
problems" (Theodossiou et al., 1996, p. 703). In such a case, higher profitability can be linked to a positive impact on the probability of acquisition. Similarly, higher liquidity, solvency, and labor productivity are also associated with lower probability of financial distress and bankruptcy but with higher probability of acquisition. Hence, between the four performance measures, there exists a hypothesized negative effect with respect to the probability of distress (bankruptcy) and a positive effect with respect to the probability of acquisition among distressed firms (Guariglia et al., 2016; Baumöhl et al., 2019; DePamphilis, 2019).

In line with similar empirical approaches in the literature, we include financial performance measures in both stages of our model. Furthermore, the correlation between financial performance variables is sufficiently low; see the correlation matrix of the variables in Appendix Table A1. Hence, the simultaneous estimation of these variables does not result in a multicollinearity issue.

\subsection{Legal form, ownership structure, and other firm-specific variables}

In Table 2, we further list a number of firm-specific controls. The choice of variables is motivated by their theoretical relevance and the proven empirical impact of firm distress and bankruptcy shown by Baumöhl et al. $(2019,2020)$.

The legal form of incorporation is represented by the limited liability company and the joint-stock company; other corporate legal forms are less frequent in our sample, and we do not assess their impact separately. A firm's corporate legal form is likely linked to its potential for firm distress - for example, Harhoff et al. (1998) showed that (West) German firms with limited liability exhibited higher growth and lower solvency as compared to other firms with full liability (e.g., joint-stock companies). However, the net effects of the legal form with respect to distress and acquisition remain ambiguous.

We further account for firms' ownership structure and corporate governance, which are both often neglected in the related literature. For ownership structure, we construct three categories: large (private) shareholders, foreign shareholders, and state ownership.

The hypothesized effects of large shareholders are often ambiguous, though. For example, the alignment hypothesis in Shleifer and Vishny (1986) advocated for the existence of a positive relationship between large shareholders and firm distress and bankruptcy. On the other hand, the negative relationship between large shareholders and firm failure is explained with the expropriation hypothesis in Claessens et al. (2000). Further, a financially distressed firm with a large private shareholder might have an incentive for a distressed acquisition as, upon the 
acquisition agreement, the controlling stake could be transferred easily from the large shareholder to a new acquirer. In this case, a large shareholder can be hypothesized to be linked to a positive impact on acquisition.

Since the 1980s, in the literature regarding industrial organization, it has been documented that foreign direct investments affect market dynamics. Generally speaking, two outcomes are possible: (i) foreign ownership increases overall sector efficiency, causing lessefficient domestic firms to exit, or (ii) a spillover effect transmits higher productivity to domestic firms, allowing them to survive even with increased competition (Franco and Weche Gelübcke, 2015). Consequently, we may hypothesize that foreign ownership can be associated with superior performance and lower probability of distress and bankruptcy. However, once a firm with foreign ownership falls into financial distress, the probability of acquisition might increase, as the ownership transfer should face fewer obstacles, allowing for a quick conclusion to the transaction and minimizing losses.

The (dummy) variables representing large shareholding and foreign ownership are not mutually exclusive. Nevertheless, we include them both in order to capture different aspects of ownership structures. Their joint use does not constitute a problem because their partial overlap is only marginal, and their correlation is negligible; in fact, the correlation coefficient between the two variables is only 0.102, as shown in Appendix Table A1.

State ownership was adopted for clear reasons. First, in emerging European markets, the state retained some control even after privatization programs were largely completed or during re-privatizations (Kočenda, 1999; Kočenda and Hanousek, 2012), and in many countries, the state still acts as a large shareholder in key companies (Iwasaki and Mizobata, 2020). Furthermore, state ownership tended to be more prevalent in certain industrial sectors, specifically in the energy sector (Matuszak and Kabaciński, 2020). It is also plausible that states, with their implicit guarantee or for political reasons, prolong the existence of some strategic firms. There is also an important link between state ownership, performance, and institutions. Szarzec et al. (2019) showed that state-owned enterprises positively contribute to growth in countries with good institutions, while their presence impairs the economy when institutional quality is low. Finally, in countries with weak institutions and/or poor investor protection, residual state ownership can enhance the value of partially privatized firms by providing monitoring and protecting dispersed minority shareholders from exploitation by controlling private owners (Megginson, 2017). Nevertheless, state ownership is traditionally associated with weaker efficiency and, thus, increased probability of distress (positive effect). However, state ownership is also linked to a controlling stake that, to some extent, represents real potential 
for effectively facilitating the ownership transfer of a financially distressed firm to a new acquirer (positive effect).

Following the example of Baumöhl et al. (2019), we include the following corporate governance proxies in the first stage of our model: board size, its nonlinear impact, and the presence of an international auditor. Hermalin and Weisbach (2003) showed that board size has a negative relation to corporate performance.

We also include a dummy variable on whether a firm is listed on a stock market-linkage to the capital market represents a firm's ability to access external funds and should have a positive impact on firm growth and survival (Musso and Schiavo, 2008) while negatively impacting the probability of distress. On the other hand, a listed firm in financial distress might not be a sufficiently appealing acquisition target due to lengthy delisting procedures, and the factor might negatively impact the probability of acquisition.

Finally, we control for firm size and age. Smaller and younger firms are less diversified and possess weaker market power than larger and older firms. Hence, their earnings are likely smaller as well. Smaller and younger firms are also often less stable and represent less difficult targets for acquirers. Therefore, firm size and age are expected to have a negative impact on the probability of financial distress as well as acquisition. Nevertheless, despite the fact that larger and older firms fail less often, Klepper and Thompson (2006) argue that the age and size of a firm may impact its exit due to other important determinants that were not included in the empirical specifications in the first place.

\subsection{Institutions and business environments}

The nexus between institutions and distressed acquisition can be illuminated from related theoretical and empirical perspectives. In seminal theoretical works, institutions have been shown to mediate an incentive structure that is ultimately linked with transaction costs (North, 1990), and high-quality institutions are indispensable for economic growth, as they facilitate efficient transactions among firms, as they improve the credibility of contract commitments, which leads to lower transaction costs (North, 1993). In this respect, a credible commitment, backed up by a solid legal environment, can be seen as important with respect to firm performance that leads to flourishing or bankruptcy. When in distress, a firm may find that a takeover by a stronger counterpart represents a potentially better solution for restructuring its assets, as a takeover may serve as an emergency resolution mechanism that avoids bankruptcy 
(Stiglitz, 1972). Distressed acquisition then represents an alternative option to bankruptcy and is also subject to the potential impact of the institutions.

An important mechanism by which institutions propagate also can be described through a different transaction costs approach (Acs, 2006; Acs and Szerb, 2007; Acs et al., 2008). In this theoretical framework, quality institutions that ensure protection of the law, democracy, and national governance or that aim to control corruption reduce firms' costs associated with the regulatory burden and uncertainty. This decreases firms' probability of distress leading to bankruptcy and implicitly impacts an alternative solution in terms of acquisition.

In terms of distress, Platt and Platt (2008; pp. 130-131) rejected the idea of a single global distress model and argued that "profound differences between regions in accounting rules, legal practices, environmental laws, and business practices" underscore the diversity of ways in which firms in various regions cope with financial distress. The differences voiced by Platt and Platt (2008) in reality reflect country differences in terms of business environment, level of institutions, and quality of legal practices. With respect to distressed acquisitions, these differences might be potentially more important than purely economic variations among countries. Moreover, Acharya et al. (2011) provided a theoretical model showing that differences in bankruptcy codes affect the anticipated liquidation value of a firm's assets, which is a specific and direct outcome of the distress resolution. In this respect, Claessens and Klapper (2005) showed a direct link between disparities in institutional background and the diversity in bankruptcy laws. In a similar vein, La Porta et al. $(1998,2013)$ emphasized the importance of legal rules that protect corporate creditors and their enforcement, and Johnson et al. (2002) showed that the nature of property rights and the availability of external finance represent distinct channels through which institutions affect the economic outcomes of firms. In addition, other studies have put forth evidence of the beneficial link between the quality of institutions and finance (Claessens et al., 2003; Dahiya and Klapper, 2007; Djankov et al., 2008; Acharya et al., 2011). Finally, Égert (2016) showed that better institutions positively affect firm productivity and that differences in productivity across countries can be explained, to a considerable extent, by cross-country variation in the overall quality of institutions.

Hence, the evidence derived from the relevant literature points to the existence of two key channels that link the institutions to (distressed) acquisitions: one is via legal codes, protection rights, and law enforcement; the second is via reforms and a market environment that impacts financial performance. In this respect, Claessens et al. (2001), Meyer et al. (2009), Chari et al. (2010), Fan et al. (2013), and Lebedev et al. (2015) bring direct evidence regarding the importance of the quality of institutions with respect to acquisitions in emerging markets. 
Furthermore, Blazy and Stef (2020) documented the importance of quality bankruptcy procedures, which are also covered in our dataset, for easing and organizing the capital transfers of distressed firms in several European emerging markets. There is also solid evidence showing that progress in reforms and the cultivation of the institutional environment is linked to economic processes in European emerging economies, namely with respect to firm performance, efficiency, survival, or recovery from financial distress (Roland, 2000; Meyer et al., 2009; Hanousek et al., 2015; Szarzec et al., 2019; Baumöhl et al., 2019; Iwasaki and Kočenda, 2020; Kočenda and Iwasaki, 2020; Stef, 2021). ${ }^{7}$

Finally, Claessens et al. (2001), Meyer et al. (2009), Chari et al. (2010), and Lebedev et al. (2015) provided compelling evidence that asymmetries in the quality of institutions between developed and emerging markets are directly important with respect to acquisitions in emerging markets. For that, we extend the set of our variables and hypothesize that differences in the quality of institutions in individual countries might impact distressed acquisitions to varying degrees. Specifically, we consider the following three cases.

First, we hypothesize that the level of legal requirements and practices in a country positively impacts business-related activities. Based on the arguments voiced by La Porta et al. (1998, 2013) and Acharya et al. (2011), prudent legal requirements, such as the enforcement of asset security during a firm's insolvency, should lower the need for distressed acquisitions, as distressed firms might go through the bankruptcy process relatively quickly. The legal practice of compliance with insolvency law should also be linked to a decrease in distressed acquisitions. Based on a large body of empirical literature, Altman (1991) argued that solvency (along with liquidity, profitability, and leverage) tends to serve as the key identifier of coming bankruptcy. As such, solvency, as a strong indicator of impending firm distress, can also be reasonably linked to a subsequent acquisition. The importance of a working insolvency regime that protects the rights of creditors and avoids the premature liquidation of viable enterprises was also stressed in a broad assessment by Claessens et al. (2001). In this respect, the level of compliance

\footnotetext{
${ }^{7}$ Specifically, with respect to distress and firm survival, Baumöhl et al. (2019) showed that the extent of corruption control ranks among the most important institutional factors that can be linked to improved likelihood that manufacturing and service firms will survive in the market. Further, Kočenda and Iwasaki (2020) showed that progress in banking reforms positively affects bank survival, and Iwasaki and Kočenda (2020) showed that progress in the liberalization and institutional reform of the enterprise sector are linked to the improved survival of service firms. Stef (2021) shows that stronger corruption control positively impacts recovery from financial distress in CEE firms.
} 
with insolvency law and its enforceability represent major institutional factors that might potentially impact the extent of distressed acquisitions in a country, ceteris paribus.

Based on the surveys of insolvency legislation carried out by the EBRD, we consider three measures related to insolvency law: (i) the level of compliance with international insolvency standards that quantifies the extent to which the country's key insolvency legislation complies with the most widely accepted international standards adopted, among others, by the World Bank and the UN Commission on International Trade Law (UNCITRAL); (ii) the extensiveness of the insolvency legal regime that quantifies the implementation of laws on the books and how the legislation works together with the available institutional framework; and (iii) the enforceability of charged assets that quantifies the legal means for instituting valid and enforceable security over assets (EBRD, 2006). Since all three measures are expressed on different scales, we normalize them to provide a directly comparable perspective of their impact. ${ }^{8}$

Furthermore, we perform a principal component analysis to create a comprehensive insolvency law index formed from our three measures described above (Appendix Table A2). This step has two advantages: we can analyze the aggregate impact of insolvency law-related institutions without omitting any particular measure, and we avoid the correlation existing between compliance with and the extensiveness of the insolvency law. The first principal component, which is extracted from the three individual measures and explains $70 \%$ of their total variance, is then used in our analysis as a proxy for their aggregate impact.

Second, we hypothesize that loose corruption control might increase distressed acquisitions if, for example, a distressed acquisition is used to prevent asset stripping. This argument is in line with that of Lebedev et al. (2015), in that better protection of shareholders' rights means fewer opportunities for controlling shareholders to expropriate minority shareholders' assets. Furthermore, Stef (2021) argues that anti-corruption institutions are able to produce positive externalities and, using a large sample of CEE firms, documents that more corruption cleansing contributed to the overcoming of financial distress and the restoration of

\footnotetext{
${ }^{8}$ With respect to the issue of enforceability of charged assets, it is specifically stated in the EBRD (2006) that "Once the money is disbursed by the creditor and there is a problem with the borrower, the creditor should be able to rely on three things: the quality of the legal documentation, the value of the collateral, and a speedy and smooth enforcement of the security. The quality of the legal documentation relating to security is directly determined by the quality of the legislation underpinning such security instruments and the implementation of such legislation by the relevant agencies and by the judiciary" (p .6). See
} Appendix B for background information of the EBRD legal surveys and the insolvency law measures. 
financial health in CEE firms. For that, we utilize data obtained from the Freedom House regarding the extent of corruption control. The original Freedom House index of corruption expresses public perceptions of corruption and ranges on a scale of 1 to 7 , where 1 represents the highest and 7 the lowest level of corruption control (Freedom House, 2018). In our analysis, we use adjusted and normalized values that are computed as 7 minus the value of the original index relevant for a specific country.

Third, we hypothesize that the level of banking reforms achieved might be linked to a decrease in distressed acquisitions as well. This argument is rooted in the fact that the extent of banking reform can be taken as a proxy for the efficiency level of lending practices. An efficient banking sector usually does not restrict lending and brings more competition among financial institutions. In emerging markets, banking sector reforms are associated with tighter lending standards that result in less bank debt in firms' capital structure, but the effect is less pronounced for financially constrained firms (Ağca et al., 2013). In this sense, improvements in the banking sector reverberate, with available financial resources being channeled to firms that might overcome financial distress that would otherwise lead to acquisition or bankruptcy. This argument is in line with the notion that financial development and the presence of alternative external sources of financing contribute to growth and reduce the prospect of bankruptcy (Musso and Schiavo, 2008; Gagliardi, 2009; Tsoukas, 2011). In order to capture the development of the banking sector, we employ the "Banking reform and interest rate liberalization" indicator of the EBRD. The indicator ranks the banking sector progress of individual countries, in terms of liberalization and institutional reforms, on a scale of 1 to $4+$ (EBRD, 2007). ${ }^{9}$

\footnotetext{
${ }^{9}$ A score of 1 denotes a little progress beyond the establishment of a two-tier system. A score of 2 marks significant liberalization of interest rates and credit allocation and limited use of directed credit or interest rate ceilings. A score of 3 represents substantial progress in establishing bank solvency and a framework for prudential supervision and regulation, full interest rate liberalization with little preferential access to cheap refinancing, and significant lending to private enterprises and a significant presence of private banks. A score of 4 means significant movement of banking laws and regulations toward standards of the Bank for International Settlements (BIS), well-functioning banking competition and effective prudential supervision, significant term lending to private enterprises, and substantial financial deepening. Finally, a score of $4+$ represents standards and performance norms of advanced industrial economies: full convergence of banking laws and regulations with BIS standards and the provision of a full set of competitive banking services (EBRD, 2007, p. 211).
} 


\section{Empirical strategy}

As we stated in the Introduction, our aim is to assess factors that significantly affect the decision to acquire a distressed firm. To empirically examine this research objective, we proceed in two stages that correspond to a Heckman two-stage probit model. In the first stage, we estimate the probability of a distressed firm's failure with a set of relevant variables. In the second stage, we employ a probability of the acquisition of a distressed firm as our dependent variable and analyze factors behind the distressed acquisition. In order to capture the initial conditions of firms immediately before the analyzed period (2007-2019), we employ a rich set of independent variables from 2006 in both stages. This approach makes it possible (i) to empirically assess the predictive power of the initial conditions and (ii) to avoid or significantly mitigate the issue of potential endogeneity or self-selection (we further deal with the issue by using the Heckman two-stage estimation procedure detailed below). A similar approach, with respect to initial conditions, was effectively used in analyses related to firm survival in European emerging markets (Baumöhl et al., 2019, 2020; Iwasaki and Kim, 2020; Iwasaki and Kočenda, 2020; Kočenda and Iwasaki, 2020; Iwasaki et al., 2021), but otherwise the researched issues substantially differ. In those studies, quantitative analysis was done based on the Cox proportional hazards model (1972), and data of failed firms are analyzed within the framework of the survival analysis (Liu, 2012) to assess the impact of various factors on the failure/survival probability of failed firms. However, in the present study, we analyze data of firms that underwent the restructuralization of their assets in a form of acquisition (under distress), and we do so within the framework of a different methodology (Heckman two-stage probit model). Finally, the goal of the present paper is also different, as we assess factors affecting decisions to acquire distressed firms and not the failure/survival chances of failed firms.

From an econometric perspective, we consider the decision to acquire a distressed firm to be the result of a dichotomous choice: to rescue a distressed firm by acquisition, or not to. As argued in the literature, in addition to the heterogeneity bias problem that could be generated by this dichotomization, the decision to acquire a distressed firm gives rise to a self-selection problem (Van de Ven and Van Praag, 1981).

We deal with the two econometric issues identified above by employing the Heckman two-step procedure, which allows us to estimate equations of the selection model and the outcome model simultaneously. Specifically, we estimate the following set of two equations that characterizes distress and acquisition models:

Distress model: $\operatorname{Pr}\left(D_{i}=1 \mid Z_{i j}\right)=\mu+\alpha Z_{i j}+\varepsilon_{i}$, 
Acquisition model: $\operatorname{Pr}\left(A_{i}=1 \mid W_{i j}\right)=\eta+\beta W_{i j}+\lambda_{i}+\epsilon_{i}$,

where, in Equation (1), $D_{i}$ is the dichotomous variable that assigns a value of 1 to firms distressed during the observation period of 2007-2019, and $Z_{i j}$ is a set of variables that affect the probability of financial distress of the $i$-th firm in the $j$-th country. Meanwhile, in Equation (2), $A_{i}$ is the dichotomous variable, which equals 1 if a distressed firm is acquired and 0 otherwise, for each $i$-th firm; $W_{i j}$ is a set of variables that influence the decision to acquire the $i$-th firm, including the institutional quality in the $j$-th country; factor $\lambda_{i}$ is obtained from the first-stage estimation and controls for sample selection bias; $\mu$ and $\eta$ are constant terms; and $\varepsilon i$ and $\epsilon_{i}$ represent error terms that satisfy the following condition:

$$
\left(\begin{array}{c}
\varepsilon_{i} \\
\epsilon_{i}
\end{array}\right) \sim \text { i.i.d. }\left(\left(\begin{array}{l}
0 \\
0
\end{array}\right),\left(\begin{array}{cc}
\sigma_{\varepsilon}^{2} & \rho_{\varepsilon \epsilon} \\
\rho_{\epsilon \varepsilon} & \sigma_{\epsilon}^{2}
\end{array}\right)\right) .
$$

We estimate both distress and acquisition models by the maximum likelihood. As Equation (3) indicates, the Heckman two-step model assumes that the error terms of Equations (1) and (2) are normally distributed with zero mean and variance and are correlated with each other. We test the null hypothesis that $\rho=0$ by a likelihood-ratio test, which compares the $\log$ likelihood of the full model with the sum of the log likelihoods for the selection and outcome models (i.e., an LR test of independence of equations). Rejection of the null hypothesis denotes that the estimators are not biased by a self-selection problem (Annunziata et al., 2019). In the estimation results, we report the Chi-squared statistic of the LR test in addition to the result of a Wald test of the null hypothesis that all coefficients are zero.

\section{Results}

\subsection{First stage: Probability of distress}

In the first stage, we estimate the distress model in specification (1), where the dependent variable is the probability of firm failure. Since the primary interest lies in the second-stage results, we report the first-stage results in Appendix Table A3 and comment on them only briefly, with an emphasis on the results for all 17 countries.

In terms of the legal form, limited liability apparently represents a more vulnerable form, as it is linked to a somewhat higher increase in the probability of distress than joint stock. Larger shareholding is a substantial factor linked to a decreased probability of distress, potentially due to the greater control it represents, the ability to marshal resources during distress events, and higher firm efficiency in general (Hanousek et al., 2015). Further results pertaining to ownership structure show that foreign ownership is also linked to a reduced probability of 
distress, while state ownership produces the opposite effect. The differences resonate with the idea that foreign ownership increases overall sector efficiency (Franco and Weche Gelübcke, 2015), but the finding should be attributed to the well-established empirical fact that state ownership of business assets is inherently less efficient than private ownership (Megginson, 2017). ${ }^{10}$ Furthermore, the non-commercial goals of state-owned enterprises seem to negatively affect their financial performance, as documented for firms operating in the energy sector in a number of European countries (Matuszak and Kabaciński, 2020). The conflict between profit and non-profit goals might easily bring those firms closer to the danger of financial distress, a fact that again corresponds to the increased probability of distress for the state ownership category.

Corporate governance factors display a small effect, in which a larger board of directors is linked to a decreased probability of distress, although its impact is reversed when the board becomes too large. Engaging an international audit firm is linked to an increased probability of distress, potentially because of the strict application of the International Financial Reporting Standards (Baumöhl et al., 2019), or due to inherent client (firm) characteristics rather than audit quality (Lawrence et al., 2011).

The overall effects of financial performance indicators and labor productivity show that better performance is linked to a decreased probability of distress; the impact is in line with results presented by Theodossiou et al. (1996). The exception is that liquidity exhibits an effect that is mostly linked with an increased probability of distress, although the effect is small. The overall effect is both intuitively plausible and consistent with earlier evidence presented by Görg and Spaliara (2014), Guariglia et al. (2016), or Baumöhl et al. (2019), albeit in a somewhat different context. Finally, older firms are associated with a mildly decreased probability of distress, potentially because of the stability that comes with years (Geroski, 1995; Geroski et al., 2010). A firm's size and listing status generally exhibit insignificant coefficients. Overall, the presented results are in line with those of a distress model presented by Baumöhl et al. (2019), albeit under a different research framework but for a similar set of emerging economies.

\footnotetext{
${ }^{10}$ Kabaciński et al. (2020) challenged the conventional view that state-owned enterprises are less efficient than their private counterparts using a large set of Polish companies; Poland has the largest share of state ownership in the European emerging markets.
} 


\subsection{Second stage: Effects of firm-specific variables on the probability of acquisition}

In the second stage, we assess the probability of acquisition by estimating specification (2). Before we present specific results, it is important to note that acquired firms differ from surviving and nonacquired failed firms (Table 3). Specifically, firms restructured by postfailure acquisition tend to have higher firm value and show better financial performance as compared with firms that were liquidated, dissolved, or that went bankrupt. Obviously, distressed acquisition firms have lower firm value and performance than firm survivors. Differences in firm value and financial performance show that distressed acquisitions are likely to occur in firms that are beyond a certain threshold in terms of those characteristics.

In the second stage of the Heckman two-step estimation, we estimate a probit model. Estimates of positive (negative) coefficients reported in Table 4 represent positive (negative) relationships between specific variables and the probability that a distressed firm will be acquired. For the purpose of interpretation, a positive (negative) coefficient means that a onepoint change in a variable in question contributes to (restrains) acquisition, and the effect depends on the value of a coefficient. For example, a coefficient of $0.1(-0.1)$ means that a onepoint change in a specific variable contributes to (curtails) the probability of acquisition by $10 \%$. It is important to note that, once a firm has already fallen into distress, a distressed acquisition represents a way for it to be restructured. For example, an indication of the performance ability of an already distressed firm should signal its better prospects for restructuring and vice versa. Furthermore, the LR test of independence of equations rejects the null hypothesis that $\rho=0$ at the $1 \%$ significance level in all six models, thus, strongly supporting the estimation strategy of employing the Heckman two-step procedure to estimate the acquisition equation (2). ${ }^{11}$

In terms of specific results, the size of the impact differs according to the specific legal form of a firm. The probability of a distressed acquisition declines for a limited liability company, but the effect is smaller than in the case of a joint-stock company. This result makes sense intuitively, as a limited liability company in the case of a takeover faces potentially fewer red-tape obstacles than does a joint-stock company that has a more complex legal structure.

Ownership structure is also found to be relevant with respect to acquisitions. The presence of a large shareholding structure can be seen as contributing to the probability of

\footnotetext{
${ }^{11}$ Appendix Table A4 reports a model with country-fixed effects and models, in which standard errors are clustered by country or industry, for robustness check (columns 1-3). Although some variables are sensitive to such differences in model specifications, the findings obtained from estimates of firm-level variables are largely unchanged.
} 
acquisition. Large shareholding means that a controlling stake can be transferred relatively easily once a firm is in financial distress, and acquisition represents a viable option for its restructuring. Both foreign and state ownership can also be linked to a rise in the probability of acquisition, but to different extents and depending on the selection of institutional variables. It is also, albeit indirectly, in line with the findings of Fan et al. (2013), who showed that distressed private companies are more sensitive to discipline and adjust their operations accordingly, as their sample of private companies includes foreign firms, along with domestic private firms and joint ventures. The positive effect of state ownership is in line with our prior contention that the state can use its controlling stake to ensure a smooth transfer to a potential acquirer.

Performance and productivity indicators exert uniformly positive impacts on the probability of acquisition, despite the fact that the coefficients are rather small. However, this is understandable because they are linked to firms that are in financial distress in the first place. Hence, any improvement in their financial performance is expected to be rather small as well. Financial ratios (ROA, liquidity, and solvency) seem to be the most important performance factors behind acquiring distressed firms. In contrast, labor productivity has a weaker impact, as the associated coefficients are smaller and lack statistical significance, in some cases. The overall outcome resonates well with the financial literature, as more profitable firms represent easier targets for effective restructuring (DePamphilis, 2019). Likewise, firms that are relatively more solvent and rely more on their own resources are more attractive for acquisition, as their capital structure is more stable and does not impact their market value (Theodossiou et al., 1996). Similar arguments can be paired with the effect of a higher liquidity ratio with respect to a higher probability of acquisition. These results are in line with the hypothesized effects and correspond to the related findings as presented by Åstebro and Winter (2012) and Miglani et al. (2015). Correlation among performance indicators is low (Appendix Table A1) and does not constitute a potential problem with respect to the reported results.

The fact that a firm is listed on the stock market is linked to a decrease in the probability of distressed acquisition, potentially because of expected bureaucratic complications related to the delisting of a firm from the stock market. This result intuitively correlates with the fact that capital markets in many researched countries are still far from well-established and suffer from low levels of liquidity, capitalization, and transparency.

Larger firms are connected with a higher probability of acquisition, although the size of the associated coefficients is quite small. Hence, the economic effect of firm size seems to be rather superficial, which is in contrast to results presented earlier by Pastena and Ruland (1986) but in accord with the findings of Peel and Wilson (1989). This evidence means that firm size, 
in terms of asset volume, is less important for the acquiring firm than is the profitability of those assets (ROA). This conclusion closely correlates with that of Theodossiou et al. (1996), who showed that the sales-generating ability of a firm's total assets is one of the most important factors for acquiring a financially distressed firm. Finally, older firms are linked to a lower probability of acquisition, as their age represents more resistance to restructuring changes. The result is consistent with the evidence of Loderer and Waelchli (2011), who showed that old firms in distress have trouble finding merger partners.

As a next step, we further exploit the cross-sectional heterogeneity of our granular data and explore the impact of a set of alternative but highly relevant firm-specific variables. Specifically, we examine the role of leverage in distressed acquisitions (Theodossiou et al., 1996) and that of the type of assets. We replace the four original performance indicators with two leverage variables and two asset-type variables and estimate our baseline model. Results are presented in Appendix Table A4 (columns 4-6). The effect of intangible assets seems to be mixed because (statistically significant) coefficients of similar magnitude exhibit alternate signs. However, a net effect indicates that a higher proportion of intangible assets is linked with a lower probability of distressed acquisition, potentially because assets of immaterial nature do not represent sufficiently lucrative motivation under circumstances of distress. On the other hand, a larger proportion of fixed assets seems to make a firm more attractive for acquisition. Hence, not only the material nature of assets but also the larger size of a firm can be taken as factors contributing to distressed acquisition (a larger proportion of fixed assets usually correlates with a firm's larger size). Furthermore, in terms of leverage, the evidence is inconclusive for a ratio of total debts to total assets, due to the statistical insignificance of coefficients. However, a larger proportion of long-term liabilities (in a firm's total liabilities) consistently decreases the appeal of firm to be acquired. The result is quite intuitive: moreleveraged firms are less attractive for acquisition because acquiring companies avoid highly leveraged firms, since these alter their optimal capital structure, resulting in their lower market value (Theodossiou et al., 1996). In this respect, the long-term nature of the debt is not a favorable factor either. The above set of results based on alternative firm-specific characteristics provides additional insights that are also broadly in line with the hypothesized effects and that correspond to the related findings presented by Åstebro and Winter (2012) and Miglani et al. (2015). Since the impact of the set of original non-performance firm-specific variables as well as that of institutions is not altered, the above step serves also as a robustness check. 
4.3 Second stage: Effects of institutions relevant for distressed acquisitions and robustness checks

Individual country-specific effects of three insolvency law factors are presented separately in Table 4, columns 1-3. Since all three factors are normalized, the coefficient values provide a direct comparison: the level of compliance with international insolvency standards and the extent of the application of insolvency legislation exhibit comparably similar and very strong impacts that are linked to less probability of distressed acquisition. The third factor, the enforceability of charged assets, exhibits an effect that is significant, but the associated coefficient is smaller than in the previous two cases; this means that the specific factor is linked to a comparably smaller decrease in the probability of acquisition. The inference from these findings is that the broader concepts of institutional quality related to insolvency laws are clearly important factors for acquiring firms - even more critical than the level of practical administration for the recovery of financial resources tied up in legal bankruptcy proceedings. This finding also resonates well with the importance of legal rules protecting corporate creditors and their enforcement, as evidenced in La Porta et al. (1998, 2013).

In accordance with the individual results, the impact of the comprehensive insolvency law index (CIL index) is strong, statistically significant, and exhibits the hypothesized impact, in that a higher level of the institutions relevant for ensuring the quality and enforcement of insolvency law correlates with a generally lower probability of distress acquisition (Table 4, column 4). Furthermore, the extent of corruption control and progress in banking reform can also be seen as strong factors linked to lowering the probability of distressed acquisition (Table 4, columns 5-6). While the impact of corruption control seems to be on par with the aggregate impact of insolvency-law institutions, the effect of banking reform is slightly lower. Nevertheless, we conclude that the impact of institutions on distressed acquisitions is both statistically and economically significant and is broadly in accord with the related empirical evidence of Claessens et al. (2001), Meyer et al. (2009), Chari et al. (2010), Fan et al. (2013), and Lebedev et al. (2015) with respect to acquisitions and of Baumöhl et al. (2019) with respect to firm survival.

In order to verify the robustness of our results on the impact of institutions, we perform a series of robustness checks. The impact of various factors, and especially institutions, may vary across industries. For this reason, we estimate our baseline model with firms grouped according to the NACE Rev. 2 classification. We form five groups: agriculture, forestry, and fishing (Section A); mining, energy, and manufacturing (Sections B-E); construction (Section F); nonfinancial services (Sections G-J, L-S); and financial services (Section K). Estimation 
results provided in Table 5 show that the impact of the CIL index is relatively level across industries. However, a detailed inspection reveals that it is strongest in agriculture, forestry, and fishing, and weakest in the mining, energy, and manufacturing. Furthermore, as compared to the CIL index, corruption control has a more substantial impact on distressed acquisitions, while banking reform can be seen as somewhat less effective. Still, both measures contribute to lowering the probability of distressed acquisition; the impact of corruption control is especially strong in the construction industry (Table 5, column 8) and in agriculture, forestry, and fishing (Table 5, column 2). A slightly lower effect is seen in nonfinancial services, followed by mining, energy, and manufacturing (Table 5, columns 11 and 5, respectively). Banking reform demonstrates similar but smaller effects, as compared to corruption control. Both factors are statistically insignificant in the financial services sector. We conclude that sectoral specifics do come into play, but industry differences do not materially affect our baseline results.

Furthermore, in Figure 2, we show the dynamics of failed firms in the researched countries, along with the rate of firm restructuring via distressed acquisition. The key observation is that, after the steep post-2007 increase, the rate of distressed acquisitions has declined remarkably in recent years. The 2007-2008 global financial shock not only struck a fatal blow to poorly performing firms but also pushed many healthy firms to financial distress and failure. The data in Figure 2 may indicate that distressed acquisitions are actively used as a tool to restructure firms damaged by an exogenous economic shock. But how does the effect of institutions evolve over time? To obtain more insight, we estimate our model on a yearly basis and show the dynamic impact of institutions on distressed acquisitions (Table 6). For this assessment, we use the CIL index as an aggregate measure of insolvency law factors, plus proxies for the level of corruption control and banking reform. In Table 6, these three institutional variables are estimated individually, but with firm-level variables, as in the baseline model. The majority of coefficients exhibit the hypothesized effect and show that better institutions relevant to acquisition decrease the probability of acquisitions. The combined impact of the insolvency law factors represented by the CIL index increased steadily after the global financial crisis but seemed to lose momentum after 2015. Thereafter, the coefficients are rather small, and the impact of these legal institutions becomes economically marginal. The impacts of corruption control and banking reform follow a pattern that is quite similar until 2015. From 2017, corruption control slightly increases the probability of distressed acquisition, while the same impact can be seen for banking reform from 2016. However, these effects are insignificant, in an economic sense, due to the small size of relevant coefficients. Overall, the role of institutions seems to be more decisive in connection with a period of severe economic 
development and, temporarily, afterward. This finding makes sense intuitively, as during a crisis, better corruption control can help keep standard bankruptcy procedures working; furthermore, a number of countries in our sample established their anti-corruption agencies shortly before the GFC or at the beginning of the post-crisis period (Stef, 2021). On the other hand, as the quality of institutions improves in the researched countries as a whole, the impact of institutional quality might also exhibit diminishing returns over time.

Finally, as a robustness check and information complementary to the dynamics presented in Table 6, we also perform an additional estimation of the baseline model with the representative country-specific macro-financial indicators instead of institutional factors. The results presented in Appendix Table A4 (columns 7-9) show that country-specific economic growth and inflation are linked with increased probability of distressed acquisitions, albeit on the margin of statistical significance, and that the impact of economic growth is also weak in the economic sense. Higher inflation seems to represent a factor that makes acquisitions more attractive, possibly due to the potential decrease in the real value of assets over a lengthy bankruptcy procedure. On the other hand, country-specific financial depth (liquid liabilities/GDP) is linked with decreased probability of distressed acquisitions; as the amount of liquid liabilities in an economy increases, acquisitions of distressed firms become less attractive. The above results also account for the aggregate macroeconomic conditions or stages of a business cycle, albeit imperfectly, due to the limited number of controls. Therefore, we accentuate the results presented in Table 6, as in the underlying specifications, we include institutional variables (along with firm-specific ones). We effectively control for economic development over time by estimating our model for successive years, for which we also adjust the number of analyzed firms. This approach allows us to provide direct results regarding the effect of institutions over time.

In the next step, we assess whether the effects of institutions vary across countries. For that, we estimate our model to perform a robustness check based on key country groups. The results are reported in Appendix Table A5. First, we exclude Russia from the full sample because the country has the largest share of observations regarding distressed acquisitions. Russia is excluded to see whether its high proportion might affect the baseline results. When we compare specific coefficients from the reduced sample (Appendix Table A5, columns 13) with the baseline results (Table 4, columns 4-6), we see that the impact of institutions in the full sample is somewhat larger than that in the reduced sample; however, Russia alone, despite its high representation in our sample, does not drive the qualitative aspect of our results. In full as well as reduced samples, a higher level of institutions contributes to a reduced probability of 
distressed acquisitions. In Russia alone, however, the role of institutions seems to be more important.

In the next step, we estimate a subsample formed only from firms in EU member countries (Appendix Table A5, columns 4-6) because it is likely that non-EU states are less developed in terms of institutional quality, and this might affect our results. Again, a comparison with our baseline results (Table 4, columns 4-6) shows that excluding the non-EU countries does not qualitatively alter the baseline findings. However, interesting evidence emerges. The extent of corruption control seems to be equally important in the full sample (Table 4, column 5), as well as the sample without non-EU states (Appendix Table A5, column 5). On the other hand, the impact of aggregate institutions and banking reform is less important in EU members (Appendix Table A5, columns 4 and 6) than in the full sample (Table 4, columns 4 and 6). We interpret this finding to be further evidence of the higher level of institutions and banking reform progress in EU members as compared to non-EU countries, but both groups exhibit similarly weak corruption control. Finally, we exclude the newest EU members (Bulgaria, Croatia, and Romania) from the sample of those that joined the EU in 2004 (Appendix Table A5, columns 7-9), as the three somewhat less-reformed economies might affect results. ${ }^{12}$ Again, a comparison with our baseline evidence (Table 4, columns 4-6) shows that the exclusion of those three countries does not qualitatively alter the baseline results. Still, the effect of institutions is, in general, less pronounced in the subsample of firms from the seven most advanced countries researched (Appendix Table A5, columns 7-9) than in the EU subsample (Appendix Table A5, columns 4-6) or the full sample (Table 4, columns 4-6). Based on evidence from the robustness checks, we conclude that individual countries do not seem to qualitatively affect the baseline results of the impact of institutions on distressed acquisitions.

As another inference from the above results, we conjecture that institutions have greater impact on distressed acquisitions in less-advanced countries (FSU and Balkan states) than in economically stronger ones (Central Europe and the Baltics). This difference might be due to weaker legal institutions relevant to firm bankruptcy and the liquidation of company assets in less-advanced countries. Because it is costlier and/or more time-consuming to deal with management failures in accordance with the law and other regulations, companies and investors in less-advanced countries might prefer to solve problems on their own via distressed

\footnotetext{
${ }^{12}$ The countries that joined the EU on May 1, 2004, and that we cover in our analysis are the Czech Republic, Estonia, Hungary, Latvia, Lithuania, Poland, and Slovakia.
} 
acquisitions, without the involvement of courts and government. In other words, in lessadvanced countries, distressed acquisitions might function as a substitute for weak formal institutions. Finally, the lesser impact of institutions in more advanced countries with higher levels of institutions provides indirect evidence of their diminishing marginal returns, as the effect of institutions is larger (smaller) for countries where the quality of broadly measured institutions is lower (higher).

\section{Conclusions}

In this paper, we analyze what factors impact acquisitions of distressed firms in European emerging markets during and after the GFC (2007-2019). We identify 23,213 distressed acquisitions in a total of 17 European economies (alphabetically): Bosnia and Herzegovina, Bulgaria, Croatia, Czech Republic, Estonia, Hungary, Latvia, Lithuania, Macedonia, Moldova, Montenegro, Poland, Romania, Russia, Serbia, Slovakia, and Ukraine. Furthermore, we use a number of theoretically and empirically motivated factors, including financial ratios, indicators related to legal form, ownership structure, and other firm-specific variables. We also use several measures that characterize the quality level of institutions in each country. Our highly salient data enable us to assess a wide array of factors in European emerging markets that are characterized by differences in economic development, as well as variations in terms of institutional quality and the legal protection of property rights.

In our empirical assessment, we proceed in two stages that correspond to a Heckman two-stage probit model. In the first stage, we estimate the probability of distressed firm failure with a set of relevant variables. In the second stage, we employ a probability of acquisition of a distressed firm as our dependent variable and analyze factors behind the distress acquisition, which is at the center of our analysis. This procedure allows us to estimate equations of the selection model and the outcome model simultaneously.

Results from the first stage are broadly in line with those of a distress model presented in relevant empirical literature. Results from the second stage indicate that firm-specific factors exhibit mainly hypothesized effects. In terms of firm performance, financial ratios (ROA, liquidity, and solvency) plus labor productivity seem to be the most important performance factors behind acquiring distressed firms, as firms that are more profitable, liquid, solvent, and productive represent easier targets for effective restructuring.

It is clearly seen that better institutions decrease the need for distressed acquisitions. Specifically, institutions related to insolvency law factors are important, in that a better level of 
compliance with international insolvency standards and the extent of the application of insolvency legislation both strongly decrease the probability of distressed acquisition. The broad concept of institutional quality related to insolvency laws is also in line with the importance of legal rules protecting corporate creditors and ensuring enforcement. The extent of corruption control and progress in banking reform are also strong factors linked to lowering the probability of distressed acquisition. The impact of broadly defined institutions does not qualitatively differ across countries, but it somewhat varies across country groups, in that institutions exhibit a greater impact on distressed acquisitions in less-advanced countries as compared to economically stronger ones. The findings can be taken as indirect evidence for the existence of diminishing marginal returns of institutions with respect to their quality.

We also find that the effect of institutions increased after the GFC, but as the economic situation improved, their impact declined. This particular result is even more important today as the coronavirus crisis evolves around the globe. We might expect an increased role of institutions for firm-level development as the crisis unveils the fragility of economic units and their need for solid ground in the form of strong and well-functioning institutions.

\section{Appendix A}

\section{Orbis Database and Our Sampling Approach}

This study uses the Orbis firm-level database, which is the main product of Bureau van Dijk (BvD) Electronic Publishing. The broad coverage, comprehensiveness, and detailed information within the database represent its worldwide well-recognized and key advantages (Kalemli-Ozcan et al., 2019; Alter and Elkedag, 2020). According to the BvD, the database is rapidly growing and currently contains more than 300 million companies around the globe. This appendix briefly describes the database and our data compilation approach.

Orbis contains firms' descriptive information, financial statements, news, market research, ratings, scanned reports, ownership information, and M\&A data. Information comes from governmental organizations and local information providers (IPs). Hence, the coverage and representativeness of the dataset for each country depend on different requirements and criteria for filing accounts with state registration organizations (Orbis, 2019).

Based on the 2006/07 archive (BvD historical vintage/historic disk), we selected companies from 17 European emerging economies that were active at the end of 2006. Then, 
we traced subsequent changes in their status using the 2019/12 archive. We manually linked these historical vintages through nine-digit and eleven-digit unique firm identifiers (BvD ID) in the same way as done by Kalemli-Ozcan et al. (2019). Overlapping data and companies that are not traceable due to missing data or changes in identifiers were dropped. Orbis also removes non-reporting companies from the database.

An initial search reveals that the BvD 2006/07 archive contains data on 2,833,567 companies in 17 researched countries, but the number is reduced to 247,501 companies that can be traced until the end of 2019. In the case of Russia, for example, about 600,000 active private (commercial) companies were registered with the state authority by the end of 2006. It can be assumed that Orbis covers $40 \%$ of these. We have 112,145 Russian companies in our dataset, accounting for approximately $50 \%$ of the Orbis dataset. This coverage is sufficiently broad.

Appendix Figure A1 shows the distribution of our sample firms. Panel (a) of the figure indicates that, in our dataset, the number of firms with 20 employees or fewer is relatively small compared to firms of other sizes, although small businesses (i.e., companies with 49 employees or fewer) have a large share (41\%). From Panels (b) and (c), it is confirmed that the distribution of the total sales and total assets is close to the normal distribution. Additionally, as displayed in Panel (d), the sectoral composition of our sample corresponds well with that of the actual one in 17 target countries.

\section{Appendix B}

\section{Background on the Institutions Represented by the Insolvency Law Variables}

As described in Subsection 2.3, we employ three EBRD indices characterizing the quality of insolvency law in order to empirically analyze country-level determinants of distressed acquisitions in European emerging markets. The original country scores for (i) compliance with insolvency law, (ii) extensiveness of insolvency law, and (iii) enforceability of insolvency law were derived from EBRD insolvency-related studies, which comprised the Insolvency Sector Assessment and the Legal Indicator Survey on Insolvency (EBRD, 2006). In the above studies, legal experts investigated the insolvency law regimes in 27 Central and East European countries and former Soviet states in an exhaustive and comprehensive manner and provided a bird's-eye view of the region from this perspective. 
The Insolvency Sector Assessment was designed to measure the extent to which a country's key insolvency legislation complied with the most widely accepted international standards adopted by the World Bank and the UN Commission on International Trade Law. The assessment focused mainly on (a) commencement of proceedings, (b) treatment of estate assets, (c) treatment of creditors, (d) reorganization processes, and (e) terminal/liquidation processes. Furthermore, according to the degree of compliance with international standards and best practices based on the above five viewpoints, the assessment classified the surveyed countries into five categories, ranging from very low to very high compliance. The results disclosed that the differences in the development level of the insolvency law regimes across the countries were greater than expected. Although some of the 17 countries included in our analysis achieved high or medium compliance (e.g., Czech Republic, Poland, Romania, Serbia), many other countries fell into the categories of low or very low compliance (e.g., Latvia, Slovenia, Ukraine). It was also revealed that no country attained the level of very high compliance.

The Legal Indicator Survey on Insolvency paid special attention to the implementation of insolvency-related laws, including timeliness, predictability, and the efficiency of the insolvency procedure. In this survey, the EBRD collaborated with private practitioners working in the relevant countries, ranging from lawyers of international law firms to independent legal consultants, with two separate scenarios: First, where insolvency proceedings are started by a creditor, and second, where such proceedings are started by a debtor. Based on their assessments, the extensiveness and enforceability of insolvency law were scored on a hundredpoint scale. The survey results emphasized the presence of remarkable variance among countries, just as in their compliance with international standards. In fact, the new EU member states tend to receive higher scores in general, but there are some exceptions (e.g., Hungary, Lithuania). On the other hand, the scores for non-EU member countries and former Soviet states were low, on average, but the evaluations of some countries were comparable to those of Central European countries (e.g., Armenia, Moldova). The original country scores for compliance, extensiveness, and the enforceability indices for the target countries in this paper are illustrated in Appendix Figure A2. As Table 3 indicates, there is an indisputable tendency for distressed acquisitions to take place in countries that exhibit lower insolvency variable country scores.

Although the above-mentioned two legal surveys were mainly based on the results of the 2004 field studies, EBRD experts stated that the situation in 2006 is well represented (EBRD, 2006). Furthermore, a similar assessment, albeit from a different angle and produced in a different period, is available with respect to the bankruptcy codes in individual countries from 
the World Bank (2013). Finally, similar scores as those reported in the EBRD studies can be obtained for individual countries with respect to confidence in the quality of contract enforcement and property rights (rule of law indicator) from the World Bank database of Worldwide Governance Indicators.

\section{References}

Acs, Z. (2006). How is entrepreneurship good for economic growth? Innovations: Technology, Governance, Globalization, 1(1), 97-107.

Acs, Z., Desai, S., Hessels, J. (2008). Entrepreneurship, economic development and institutions. Small Business Economics, 31(3), 219-234.

Acs, Z., Szerb, L. (2007). Entrepreneurship, economic growth and public policy. Small Business Economics, 28(2-3), 109-122.

Acharya, V., Sundaram, R., John, K. (2011). Cross-country variations in capital-structures: The role of bankruptcy codes. Journal of Financial Intermediation, 20(1), 25-54.

Ağca, Ş., De Nicolò, G., Detragiache, E. (2013). Banking sector reforms and corporate leverage in emerging markets. Emerging Markets Review, 17, 125-149.

Alter A., Elekdag, S. (2020). Emerging market corporate leverage and global financial conditions. Journal of Corporate Finance, 62, Article 101590.

Altman, E. I. (1991). Techniques for predicting bankruptcy and their use in a financial turnaround. In S. N. Levine (ed.), Investing in bankruptcies and turnarounds: Spotting investment values in distressed businesses. New York: Harper-Collins Publishers.

Andrade, G., Mitchell, M., Stafford, E. (2001). New evidence and perspectives on mergers. Journal of Economic Perspectives 15(2), 103-120.

Annunziata, A., Agovino, M., Mariani, A. (2019). Sustainability of Italian families' food practices: Mediterranean diet adherence combined with organic and local food consumption. Journal of Cleaner Production, 206(2), 86-96.

Åstebro, T. B., Winter, J. K. (2012). More than a dummy: The probability of failure, survival and acquisition of private firms in financial distress. European Management Review, 9(1), 1-17.

Baumöhl, E., Iwasaki, I., Kočenda, E. (2019). Institutions and determinants of firm survival in European emerging markets. Journal of Corporate Finance, 58, 431-453.

Baumöhl, E., Iwasaki, I., Kočenda, E. (2020). Firm survival in new EU member states. Economic Systems, 44(1), 100743.

Blazy, R., Stef, N. (2020). Bankruptcy procedures in the post-transition economies. European Journal of Law and Economics, 50, 7-64.

Bruton, G. D., Oviatt, B. M., White, M. A. (1994). Performance of acquisitions of distressed firms. Academy of Management Journal, 37(4), 972-989.

Chari, A., Ouimet, P. P., Tesar, L. L. (2010). The value of control in emerging markets. Review of Financial Studies, 23(4), 1741-1770.

Claessens, S., Djankov, S., Klapper, L. (2003). Resolution of corporate distress in East Asia. Journal of Empirical Finance, 10 (1-2), 199-216.

Claessens, S., Djankov, S., Lang, L. H. P. (2000). The separation of ownership and control in East Asian corporations. Journal of Financial Economics, 58(1-2), 81-112. 
Claessens, S., Djankov, S., Mody, A. (Eds.) (2001). Resolution of financial distress: An international perspective on the design of bankruptcy laws. Washington, D.C.: The World Bank.

Claessens, S., Klapper, L. (2005). Bankruptcy around the world: Explanations of its relative use. American Law and Economics Review, 7(1), 253-283.

Clark, K., Ofek, E. (1994). Mergers as a means of restructuring distressed firms: An empirical investigation. Journal of Financial and Quantitative Analysis, 29(4), 541-565.

Cox, D. R. (1972). Regression models and life-tables. Journal of the Royal Statistical Society. Series B, 34(2), 187-220.

Cubeddu, L., Culiuc, A., Fayad, G., Gao, Y., Kochhar, K., Kyobe, A., Oner, C., Perrelli, R., Sanya, S., Tsounta, E., Zhang, Z. (2014). Emerging markets in transition: Growth prospects and challenges. IMF Staff Discussion Notes No. 14/6. International Monetary Fund.

Dahiya, S., Klapper, L. (2007). Who survives? A cross-country comparison. Journal of Financial Stability, 3(3), 261-278.

Darvas, Z. (2011). Beyond the crisis: Prospects for emerging Europe. Comparative Economic Studies, 53(2), 261-290.

DePamphilis, D. (2019). Mergers, acquisitions, and other restructuring activities: An integrated approach to process, tools, cases, and solutions. Amsterdam: Academic Press.

De Paula, G. M., Ferraz, J. C., Iootty, M. (2002). Economic liberalization and changes in corporate control in Latin America. Developing Economies, 40(4), 467-496.

Djankov, S., Hart, O., McLiesh, C., Shleifer, A. (2008). Debt enforcement around the world. Journal of Political Economy, 116(6), 1105-1149.

EBRD (European Bank for Reconstruction and Development) (2006). Law in transition online 2006: Focus on Central Europe. London: EBRD.

EBRD (2007). Transition report 2007: People in transition, London: EBRD.

Eckbo, B. E. (2014). Corporate takeovers and economic efficiency. Annual Review of Financial Economics, 6(1), 51-74.

Égert, B. (2016). Regulation, institutions, and productivity: New macroeconomic evidence from OECD countries. American Economic Review, 106(5), 109-113 .

Eisenberg, T., Sundgren, S., Wells, M. T. (1998). Larger board size and decreasing firm value in small firms. Journal of Financial Economics, 48(1), 35-54.

Estrin, S., Hanousek, J., Kočenda, E., Svejnar, J. (2009). Effects of privatization and ownership in transition economies. Journal of Economic Literature, 47(3), 699-728.

Evenett, S. J. (2004). The cross-border mergers and acquisitions wave of the late 1990s. In R. E. Baldwin, L. A. Winters (Eds.), Challenges to globalization: Analyzing the economics (pp. 411-469). Chicago: University of Chicago Press.

Fan, J. P. H., Huang, J., Zhu, N. (2013). Institutions, ownership structures, and distress resolution in China. Journal of Corporate Finance, 23, 71-87.

Franco, C., Weche Gelübcke, J. P. (2015). The death of German firms: What role for foreign direct investment? The World Economy, 38(4), 677-703.

Freedom House (2018). Nations in transit 2018: Confronting illiberalism. Washington, D.C. and New York: Freedom House. Available at: https://freedomhouse.org/report/nations-transit/nationstransit-2018.

Gagliardi, F. (2009). Financial development and the growth of cooperative firms. Small Business Economics, 32(2), 439-464.

Geroski, P. A. (1995). What do we know about entry? International Journal of Industrial Organization, 13(4), 421-440. 
Geroski, P. A., Mata, J., Portugal, P. (2010). Founding conditions and the survival of new firms. Strategic Management Journal, 31(5), 510-529.

Görg, H., Spaliara, M.-E. (2014). Exporters in the financial crisis. National Institute Economic Review, 228(1), 49-57.

Guariglia, A., Spaliara, M.-E., Tsoukas, S. (2016). To what extent does the interest burden affect firm survival? Evidence from a panel of UK firms during the recent financial crisis. Oxford Bulletin of Economics and Statistics, 78(4), 576-594.

Hanousek, J., Kočenda, E., Shamshur, A. (2015). Corporate efficiency in Europe. Journal of Corporate Finance, 32, 24-40.

Harhoff, D., Stahl, K., Woywode, M. (1998). Legal form, growth and exit of West German firmsEmpirical results for manufacturing, construction, trade and service industries. Journal of Industrial Economics, 46(4), 453-488.

Hermalin, B. E., Weisbach, M. S. (2003). Boards of directors as an endogenously determined institution: A survey of the economic literature. Economic Policy Review, 9, 7-26.

Hotchkiss, E. S., Mooradian, R. M. (1998). Acquisitions as a means of restructuring firms in Chapter 11. Journal of Financial Intermediation, 7(3), 240-262.

Iwasaki, I., Kim, B-Y. (2020). Legal forms, organizational architecture, and firm failure: A large survival analysis of Russian corporations. European Journal of Law \& Economics, 49(2), 227-275.

Iwasaki, I., Kočenda, E. (2020). Survival of service firms in European emerging economies. Applied Economics Letters, 27(4), 340-348.

Iwasaki, I., Kočenda, E., Shida, Y. (2021). Institutions, financial development, and small business survival: Evidence from European emerging markets. Small Business Economics. (In press)

Iwasaki, I., Mizobata., S. (2018). Post-privatization ownership and firm performance: A large metaanalysis of the transition literature. Annals of Public and Cooperative Economics, 89(2), 263-322.

Iwasaki, I., Mizobata., S. (2020). Ownership concentration and firm performance in European emerging economies: A meta-analysis. Emerging Markets Finance \& Trade, 56(1), 32-67.

Johnson, S., McMillan, J., Woodruff, C. (2002) Property rights and finance. American Economic Review, 92(5), 1335-1356.

Kabaciński, B., Kubiak, J., Szarzec, K. (2020). Do state-owned enterprises underperform compared to privately owned companies? An examination of the largest polish enterprises. Emerging Markets Finance and Trade, 56(13), 3174-3192.

Kalemli-Ozcan, S., Sorensen, B., Villegas-Sanchez, C., Volosovych, V., Yesiltas, S. (2019). How to construct nationally representative firm-level data from Orbis global database. NBER Working Paper No. 21558, September 2015, Revised December 2019.

Klepper, S., Thompson, P. (2006). Submarkets and the evolution of market structure. RAND Journal of Economics, 37(4), 861-886.

Kočenda, E. (1999). Residual state property in the Czech Republic. Eastern European Economics, 37(5), $6-35$.

Kočenda, E., Hanousek, J. (2012). State ownership and control in the Czech Republic. Economic Change and Restructuring, 45(3), 157-191.

Kočenda, E., Iwasaki, I. (2020). Bank survival in Central and Eastern Europe. International Review of Economics and Finance, 69, 860-878.

La Porta, R., Lopez-de-Silanes, F., Shleifer, A., Vishny, R. W. (1998). Law and finance. Journal of Political Economy, 106(6), 1113-1155. 
La Porta, R., Lopez-de-Silanes, F., Shleifer, A. (2013). Law and finance after a decade of research. In G. M. Constantinides, M. Harris, R. M. Stulz (Eds.), Handbook of the Economics of Finance (Vol. 2, Part A, pp. 425-491). Elsevier.

Lawrence, A., Minutti-Meza, M., Zhang, P. (2011). Can Big 4 versus non-Big 4 differences in auditquality proxies be attributed to client characteristics? Accounting Review, 86(1), 259-286.

Lebedev, S., Peng, M. W., Xie, E., Stevens, C. E. (2015). Mergers and acquisitions in and out of emerging economies. Journal of World Business, 50(4), 651-662.

Liu, X. (2012). Survival analysis: models and Applications. Chichester: John Wiley \& Sons.

Loderer, C. F., Waelchli, U. (2011). Firm age and performance. Available at SSRN: http://dx.doi.org/10.2139/ssrn.1342248

Matuszak, P., Kabaciński, B. (2020). Non-commercial goals and financial performance of state-owned enterprises: Some evidence from the electricity sector in the EU countries. Journal of Comparative Economics. (Forthcoming)

Megginson, W. L. (2017). Privatization, state capitalism, and state ownership of business in the 21st century. Foundations and Trends in Finance, 11(1-2), 1-153.

Meier, J. M., Servaes, H. (2019). The bright side of fire sales. Review of Financial Studies, 32(11), $4228-4270$.

Meyer, K. E., Estrin, S., Bhaumik, S. K., Peng, M. W. (2009). Institutions, resources, and entry strategies in emerging economies. Strategic Management Journal, 30(1), 61-80.

Miglani, S., Ahmed, K., Henry, D. (2015). Voluntary corporate governance structure and financial distress: Evidence from Australia. Journal of Contemporary Accounting \& Economics, 11(1), 18 30.

Mody, A., Negishi, S. (2001). Cross-border mergers and acquisitions in East Asia: Trends and implications. Finance and Development, 38 (1), 6-9.

Musso, P., Schiavo, S. (2008). The impact of financial constraints on firm survival and growth. Journal of Evolutionary Economics, 18(2), 135-149.

Nesvold, H. P., Anapolsky, J., Lajoux, A. R. (2010). The art of distressed M\&A: Buying, selling, and financing troubled and insolvent companies. New York: McGraw Hill Professional.

North, D. C. (1990). Institutions, institutional change and economic performance. Cambridge University Press, Cambridge.

North, D. C. (1993). Institutions and credible commitment. Journal of Institutional and Theoretical Economics, 149(1), 11-23.

Orbis (2019). Orbis Internet User Guide, November 2019.

Pastena, V., Ruland, W. (1986). The merger/bankruptcy alternative. Accounting Review, 61(2), 288301.

Peel, M. J., Wilson, N. (1989). The liquidation/merger alternative. Some results for the UK corporate sector. Managerial and Decision Economics, 10(3), 209-220.

Platt, H. D., Platt, M. B. (2008). Financial distress comparison across three global regions. Journal of Risk and Financial Management, 1(1), 129-162.

Roland, G. (2000). Transition and economics: Politics, markets and firms. Cambridge: MIT Press.

Schweizer, L., Nienhaus, A. (2017). Corporate distress and turnaround: Integrating the literature and directing future research. Business Research, 10(1), 3-47.

Shleifer, A., Vishny, R. W. (1986). Large shareholders and corporate control. Journal of Political Economy, 94(3), 461-488.

Stef, N. (2021). Institutions and corporate financial distress in Central and Eastern Europe. Burgundy School of Business, Dijon, France, Working Paper. 
Stiglitz, J. E. (1972). Some aspects of the pure theory of corporate finance: Bankruptcies and takeover. The Bell Journal of Economics and Management Science, 3(2), 458-482.

Szarzec, K., Dombi, Á., Matuszak, P. (2019). State-owned enterprises and economic growth: Evidence from the post-Lehman period. Working Paper. Poznan: Poznan University of Economics and Business; Budapest: Eötvös Loránd University.

Theodossiou, P., Kahya, E., Saidi, R., Philippatos, G. (1996). Financial distress and corporate acquisitions: Further empirical evidence. Journal of Business Finance and Accounting, 23(5-6), 699-719.

Tsoukas, S. (2011). Firm survival and financial development: Evidence from a panel of emerging Asian economies. Journal of Banking \& Finance, 35(7), 1736-1752.

Van de Ven, W. P. M. M., Van Praag, B. M. S. (1981). The demand for deductibles in private health insurance: A probit model with sample selection. Journal of Econometrics, 17(2), 229-252.

World Bank. (2013). Smarter regulations for small and medium-size enterprises. Doing Business Report 2013, Washington, D.C.: World Bank.

Xu, P. (2019). Exit of small businesses: Differentiating between insolvency, voluntary closures and $M \& A$. RIETI Discussion Paper Series 19-E-051, Research Institute of Economy, Trade and Industry. 
Figure 1. Survival status of 247,501 firms in 17 European emerging economies at the end of 2019

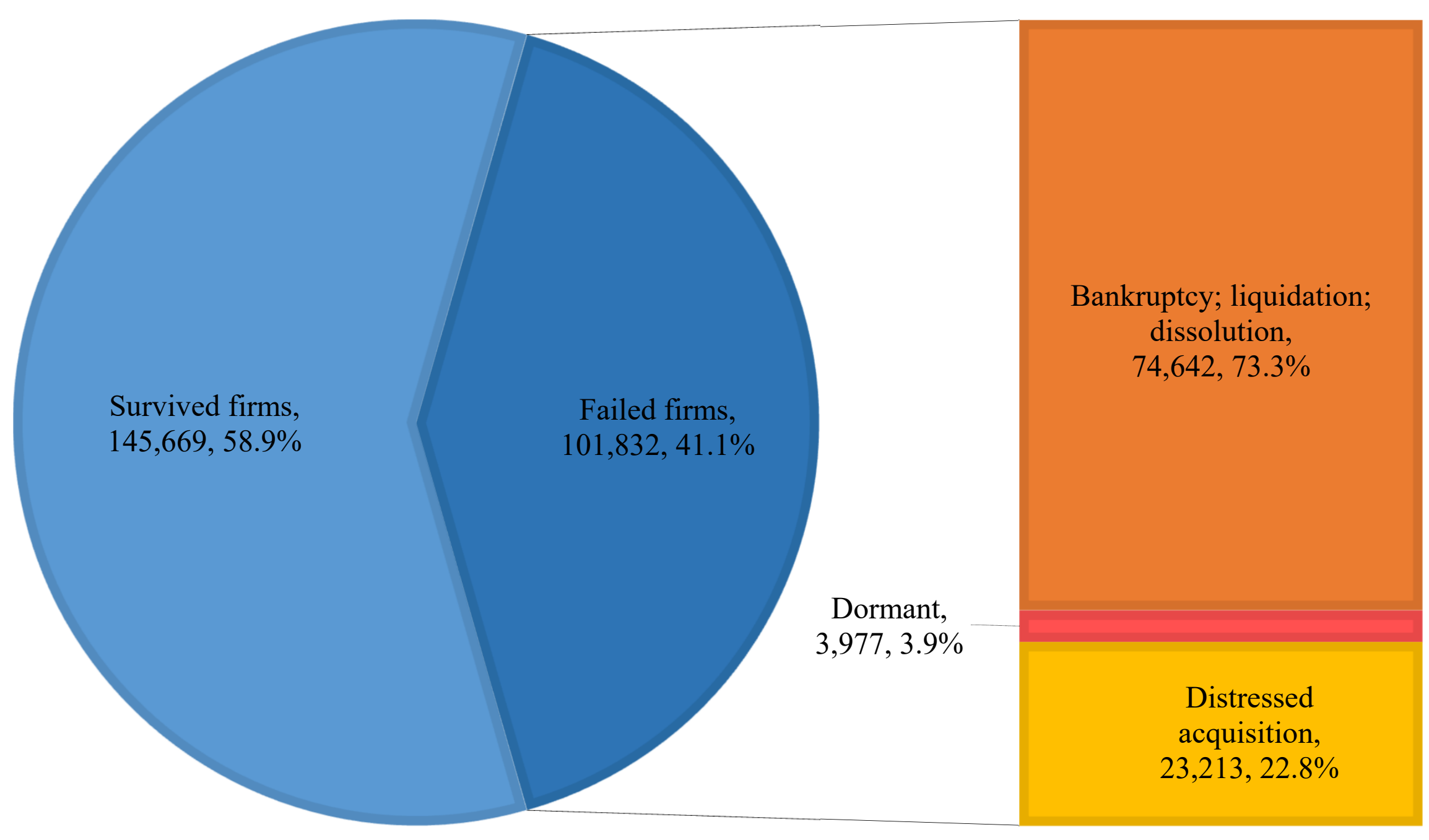


Figure 2. Dynamics of firm failure and distressed acquisitions in 17 European emerging economies during the period from 2007 to 2019

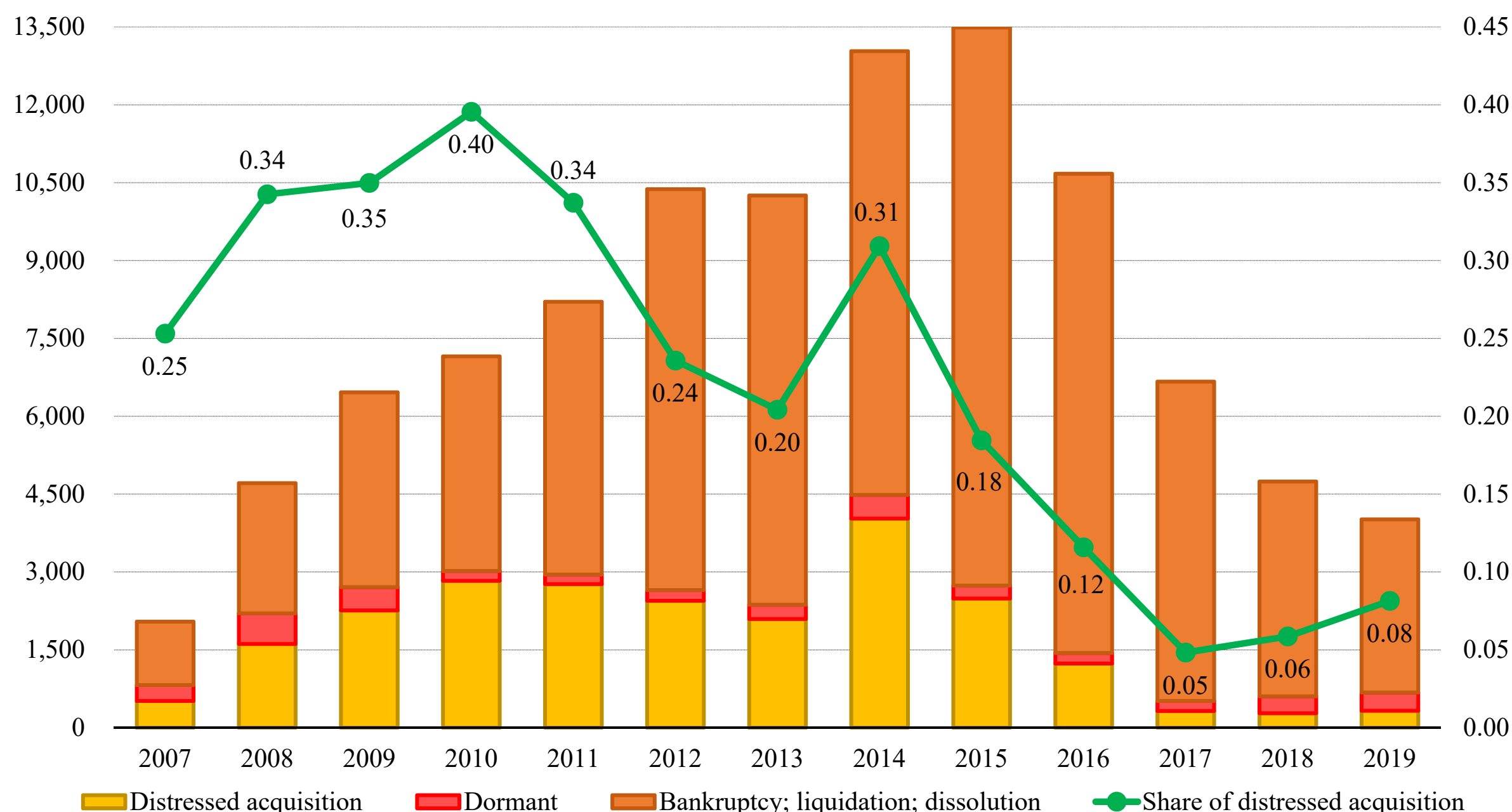

Note: The left axis is the number of failed firms, while the right axis is the share of distressed acquisitions in failed firms. 
Table 1. Survival status of 247,501 firms and share of distressed acquisitions in failed firms in 17 European emerging economies, $2007-2019$

\begin{tabular}{|c|c|c|c|c|c|c|c|c|}
\hline & \multirow{2}{*}{$\begin{array}{l}\text { Number of } \\
\text { firms } \\
\text { operating at } \\
\text { the end of } \\
2006 \\
\text { (N) }\end{array}$} & \multirow{2}{*}{$\begin{array}{l}\text { Number of } \\
\text { surviving } \\
\text { firms } \\
\text { (survivors) } \\
\text { by the end of } \\
2019 \\
\text { (A) }\end{array}$} & \multicolumn{4}{|c|}{ Number of failed firms by the end of 2019} & \multirow[b]{2}{*}{$\begin{array}{c}\text { Failure rate }^{\mathrm{a}} \\
\qquad(\mathrm{F} / \mathrm{N})\end{array}$} & \multirow{2}{*}{$\begin{array}{c}\text { Share of } \\
\text { distressed } \\
\text { acquisitions } \\
\text { in failed } \\
\text { firms }(\mathrm{D} / \mathrm{F})\end{array}$} \\
\hline & & & $\begin{array}{l}\text { Total failed } \\
\text { firms } \\
(\mathrm{F}=\mathrm{B}+\mathrm{C}+\mathrm{D})\end{array}$ & $\begin{array}{l}\text { Bankruptcy, } \\
\text { liquidation, } \\
\text { dissolution } \\
\text { (B) }\end{array}$ & $\begin{array}{l}\text { Dormant } \\
\text { (C) }\end{array}$ & $\begin{array}{l}\text { Distressed } \\
\text { acquisition } \\
\text { (D) }\end{array}$ & & \\
\hline All 17 European emerging economies & 247,501 & 145,669 & 101,832 & 74,642 & 3,977 & 23,213 & 0.411 & 0.228 \\
\hline \multicolumn{9}{|l|}{ Breakdown by country group } \\
\hline Central European countries $^{\mathrm{b}}$ & 41,395 & 31,618 & 9,777 & 7,235 & 969 & 1,573 & 0.236 & 0.161 \\
\hline East European countries ${ }^{c}$ & 43,040 & 29,327 & 13,713 & 12,373 & 715 & 625 & 0.319 & 0.046 \\
\hline Baltic countries $^{\mathrm{d}}$ & 10,634 & 7,109 & 3,525 & 3,190 & 51 & 284 & 0.331 & 0.081 \\
\hline FSU countries $^{\mathrm{e}}$ & 152,432 & 77,615 & 74,817 & 51,844 & 2,242 & 20,731 & 0.491 & 0.277 \\
\hline \multicolumn{9}{|l|}{ Breakdown by sector (NACE Rev. 2 section) } \\
\hline Agriculture, forestry, and fishing (Section A) & 16,990 & 11,498 & 5,492 & 3,808 & 130 & 1,554 & 0.323 & 0.283 \\
\hline Mining, energy, and manufacturing (Sections B-E) & 71,759 & 46,466 & 25,293 & 19,554 & 949 & 4,790 & 0.352 & 0.189 \\
\hline Construction (Section F) & 29,937 & 15,194 & 14,743 & 11,392 & 574 & 2,777 & 0.492 & 0.188 \\
\hline Nonfinancial services (Sections G-J, L-S) & 125,967 & 71,051 & 54,916 & 38,953 & 2,267 & 13,696 & 0.436 & 0.249 \\
\hline Financial services (Section K) & 2,848 & 1,460 & 1,388 & 935 & 57 & 396 & 0.487 & 0.285 \\
\hline
\end{tabular}

Notes:

${ }^{a}$ Denotes share of failed firms in firms operating at the end of 2006

${ }^{\mathrm{b}}$ Czech Republic, Hungary, Poland, and Slovakia

${ }^{\mathrm{c}}$ Bosnia and Herzegovina, Bulgaria, Croatia, Macedonia, Montenegro, Romania, and Serbia

${ }^{\mathrm{d}}$ Estonia, Latvia, and Lithuania

${ }^{\mathrm{e}}$ Moldova, Russia, and Ukraine

Source: Bureau van Dijk (BvD) Orbis database (https://webhelp.bvdep.com) 
Table 2. Definitions and descriptive statistics of dependent variables used in the empirical analysis

\begin{tabular}{|c|c|c|c|c|}
\hline \multirow{2}{*}{ Variable name } & \multirow{2}{*}{ Definition } & \multicolumn{3}{|c|}{ Descriptive statistics } \\
\hline & & Mean & S.D. & Median \\
\hline \multicolumn{5}{|l|}{ Firm-specific variables } \\
\hline Joint-stock company & Dummy variable for open joint-stock companies & 0.193 & 0.395 & 0 \\
\hline Limited liability company & Dummy variable for limited liability companies & 0.555 & 0.497 & 1 \\
\hline Large shareholding & Dummy for firms with a dominant and block shareholder(s) & 0.806 & 0.396 & 1 \\
\hline Foreign ownership & Dummy for ultimate ownership of foreign investors & 0.042 & 0.201 & 0 \\
\hline State ownership & Dummy for ultimate ownership of the state & 0.052 & 0.221 & 0 \\
\hline Board size & Number of recorded members of the board of directors & 1.862 & 2.169 & 1 \\
\hline International audit firm & Dummy for firms that employ an international audit firm as external auditor & 0.013 & 0.115 & 0 \\
\hline ROA & Return on total assets $(\%)^{\mathrm{a}, \mathrm{b}}$ & 0.445 & 3.468 & 0.100 \\
\hline Liquidity & Liquidity ratio $(\%)^{b, c}$ & 0.209 & 1.022 & 0.000 \\
\hline Solvency & Solvency ratio $(\%)^{b, d}$ & 0.201 & 5.107 & 0.346 \\
\hline Labor productivity & Natural logarithm of operating revenue per employee in Euros ${ }^{b}$ & 1.411 & 6.066 & 0.000 \\
\hline Listed on stock market & Dummy for listed firms & 0.021 & 0.142 & 0 \\
\hline Firm size & Natural logarithm of total assets in Euros ${ }^{b}$ & 21.404 & 104.404 & 1.259 \\
\hline Firm age & Years in operation since the company's establishment ${ }^{\mathrm{b}}$ & 0.144 & 2.342 & 0.000 \\
\hline \multicolumn{5}{|l|}{ Institutional variables $^{\mathrm{e}}$} \\
\hline Compliance with insolvency law & Normalized value of the EBRD indicator of the level of compliance with international insolvency standal & -0.240 & 0.948 & 0.000 \\
\hline Extensiveness of insolvency law & Normalized value of the EBRD indicator of the extensiveness of insolvency legal regimes & -0.267 & 0.878 & -0.030 \\
\hline Enforceability of insolvency law & Normalized value of the EBRD indicator of the enforceability of charged assets & -0.496 & 0.779 & -1.067 \\
\hline Comprehensive insolvency law index & First principal component score of the three insolvency law variables above ${ }^{f}$ & -0.005 & 1.450 & 0.564 \\
\hline Corruption control & Adjusted and normalized value of the Freedom House index of corruption ${ }^{g}$ & -0.676 & 0.994 & -1.419 \\
\hline Banking reform & Normalized value of the EBRD index of banking sector reform & -0.472 & 0.832 & -0.609 \\
\hline \multicolumn{5}{|l|}{ Alternative variables ${ }^{\mathrm{h}}$} \\
\hline Economic growth & Real GDP growth rate $(\%)$ & 7.160 & 1.083 & 7.400 \\
\hline Inflation & Change in comsumer price index $(\%)$ & 7.793 & 2.903 & 9.100 \\
\hline Financial depth & Liquid liabilities to GDP & -0.507 & 0.942 & -1.180 \\
\hline Intangible assets/total assets & Intangible assets to total assets ${ }^{\mathrm{b}}$ & 0.023 & 0.075 & 0.000 \\
\hline Fixed assets/total assets & Fixed assets to total assets ${ }^{\mathrm{b}}$ & 0.037 & 0.440 & 0.033 \\
\hline Long-term liabilities/total liabilities & Long-term liabilities to total liabilities ${ }^{\mathrm{b}}$ & 0.183 & 0.563 & 0.000 \\
\hline Total debts/total assets & Total debts to total assets ${ }^{\mathrm{b}}$ & -0.002 & 0.026 & 0.000 \\
\hline \multicolumn{5}{|c|}{$\begin{array}{l}\text { Notes: The independent variables capture the firm and country-wide initial conditions in } 2006 \text { for firm failures and distressed acquisitions observed during the period of } 2007-2019 \text {. The correlation } \\
\text { matrix of the variables from joint-stock company to banking reform is reported in Appendix Table A1. Due to the lack of country-level data, Montenegro is excluded from empirical analysis. }\end{array}$} \\
\hline \multicolumn{5}{|c|}{${ }^{a}$ Computed using the following formula: (profit before tax/total assets) $\times 100$} \\
\hline \multicolumn{5}{|c|}{ b Industry-adjusted value based on the method proposed by Eisenberg et al. (1998) } \\
\hline \multicolumn{5}{|c|}{${ }^{\mathrm{C}}$ Computed using the following formula: $(($ current assets - stocks $) /$ current liabilities $) \times 100$} \\
\hline \multicolumn{5}{|c|}{${ }^{\mathrm{d}}$ Computed using the following formula: (shareholder funds/total assets) $\times 100$} \\
\hline \multicolumn{5}{|c|}{${ }^{\mathrm{e}}$ Descriptive statistics are computed using firm-level observations. } \\
\hline \multicolumn{5}{|c|}{${ }^{\mathrm{f}}$ Appendix Table A2 reports the estimation results of the principal component analysis. } \\
\hline \multicolumn{5}{|c|}{${ }^{\mathrm{g}}$ Computed as 7 minus the value of the original index, which ranges between 1.00 (best) and 7.00 (worst) } \\
\hline${ }^{\mathrm{h}}$ Used for a robustness check in Appendix & Table A5 & & & \\
\hline
\end{tabular}


Table 3. Univariate comparison between companies with different survival statuses

\begin{tabular}{|c|c|c|c|c|c|c|c|c|c|c|c|}
\hline \multirow{3}{*}{ Variable name } & \multicolumn{6}{|c|}{ Surival status at the end of 2019} & \multicolumn{3}{|c|}{$\begin{array}{l}\text { Univariate comparison among three survival } \\
\text { statuses }\end{array}$} & \multicolumn{2}{|c|}{$\begin{array}{c}\text { Univariate comparison between } \\
\text { bankruptcy/liquidation/dissolution } \\
\text { and distressed acquisition }\end{array}$} \\
\hline & \multicolumn{2}{|c|}{ Survivor } & \multicolumn{2}{|c|}{$\begin{array}{l}\text { Bankruptcy, } \\
\text { liquidation, dissolution }\end{array}$} & \multicolumn{2}{|c|}{ Distressed acquisition } & \multirow{2}{*}{$\begin{array}{l}\text { ANOVA } \\
\qquad(F)\end{array}$} & \multirow{2}{*}{$\begin{array}{l}\text { Bartlett's test } \\
\qquad\left(\chi^{2}\right)\end{array}$} & \multirow{2}{*}{$\begin{array}{l}\text { Kruskal-Wallis } \\
\text { equality-of- } \\
\text { populations rank } \\
\text { test }\left(\chi^{2}\right)\end{array}$} & \multirow{2}{*}{$\begin{array}{l}\text { Test for equality } \\
\text { of means }(t) \text { or } \\
\text { test for equality } \\
\text { of proportions } \\
(z)\end{array}$} & \multirow{2}{*}{$\begin{array}{l}\text { Wilcoxon rank- } \\
\text { sum test }(z)\end{array}$} \\
\hline & Mean & Median & Mean & Median & Mean & Median & & & & & \\
\hline \multicolumn{12}{|l|}{ Firm-specific variables } \\
\hline Joint-stock company & 0.204 & 0 & 0.187 & 0 & 0.146 & 0 & $230.150^{* * *}$ & $686.976^{* * *}$ & $214.657^{* * *}$ & $14.351^{* * *}$ & $14.351^{* * *}$ \\
\hline Limited liability company & 0.528 & 1 & 0.585 & 1 & 0.629 & 1 & $615.960^{* * *}$ & $50.706^{* * *}$ & $908.122^{* * *}$ & $-11.862^{* * *}$ & $-11.862^{* * *}$ \\
\hline Large shareholding & 0.850 & 1 & 0.727 & 1 & 0.780 & 1 & $2505.490^{* * *}$ & $5200.000^{* * *}$ & $2306.351^{* * *}$ & $-16.062^{* * *}$ & $-16.062^{* * *}$ \\
\hline Foreign ownership & 0.053 & 0 & 0.024 & 0 & 0.035 & 0 & $536.150^{* * *}$ & $14000.000^{* * *}$ & $129.402^{* * *}$ & $-9.146^{* * *}$ & $-9.146^{* * *}$ \\
\hline State ownership & 0.055 & 0 & 0.037 & 0 & 0.076 & 0 & $330.740^{* * *}$ & $5500.000^{* * *}$ & $96.843^{* * *}$ & $-25.012^{* * *}$ & $-25.012^{* * *}$ \\
\hline Board size & 2.082 & 1 & 1.602 & 1 & 1.317 & 1 & $2049.070^{* * *}$ & $11000.000^{* * *}$ & $5225.420^{* * *}$ & $21.418^{* * *}$ & $15.721^{* * *}$ \\
\hline International audit firm & 0.017 & 0 & 0.005 & 0 & 0.019 & 0 & $271.220^{* * *}$ & $29000.000^{* * *}$ & $21.506^{* * *}$ & $-19.844^{* * *}$ & $-19.844^{* * *}$ \\
\hline ROA & 0.871 & 1.243 & -0.212 & -1.364 & -0.046 & -1.221 & $2523.220^{* * *}$ & $87.753^{* * *}$ & $5262.776^{* * *}$ & $-6.148^{* * *}$ & $-6.196^{* * *}$ \\
\hline Liquidity & 0.287 & 0.212 & 0.069 & -0.265 & 0.187 & -0.141 & $1046.760^{* * *}$ & $1100.000^{* * *}$ & $2690.910^{* * *}$ & $-15.708^{* * *}$ & $-13.360^{* * *}$ \\
\hline Solvency & 1.105 & 2.759 & -1.321 & -3.242 & -0.479 & -2.522 & $5660.220^{* * *}$ & $126.208^{* * *}$ & $10136.367^{* * *}$ & $-21.908^{* * *}$ & $-20.476^{* * *}$ \\
\hline Labor productivity & 1.742 & 1.018 & 0.949 & -0.732 & 0.923 & -1.162 & $464.560^{* * *}$ & $566.188^{* * *}$ & $992.364^{* * *}$ & 0.577 & $6.092^{* * *}$ \\
\hline Listed on stock market & 0.026 & 0 & 0.016 & 0 & 0.003 & 0 & $320.040^{* * *}$ & $30000.000^{* * *}$ & $38.833^{* * *}$ & $15.115^{* * *}$ & $15.114^{* * *}$ \\
\hline Firm size & 26.261 & 8.942 & 13.772 & -8.795 & 16.334 & -9.948 & $363.030^{* * *}$ & $39000.000^{* * *}$ & $989.064^{* * *}$ & $-5.020^{* * *}$ & $1.782^{*}$ \\
\hline Firm age & 0.503 & 1.000 & -0.313 & -1.414 & -0.640 & -1.414 & $4596.390^{* * *}$ & $670.225^{* * *}$ & $9987.427^{* * *}$ & $19.596^{* * *}$ & $17.081^{* * *}$ \\
\hline \multicolumn{12}{|l|}{ Institutional variables } \\
\hline Compliance with insolvency law & -0.236 & 0.000 & -0.086 & 0.000 & -0.758 & 0.000 & $4633.070^{* * *}$ & $5000.000^{* * *}$ & $6039.507^{* * *}$ & $106.239^{* * *}$ & $94.724^{* * *}$ \\
\hline Extensiveness of insolvency law & -0.273 & -0.030 & -0.118 & -0.030 & -0.703 & -0.030 & $4070.860^{* * *}$ & $4000.000^{* * *}$ & $5515.403^{* * *}$ & $99.340^{* * *}$ & $86.839^{* * *}$ \\
\hline Enforceability of insolvency law & -0.393 & -0.342 & -0.636 & -1.067 & -0.692 & -1.067 & $3304.980^{* * *}$ & $9000.000^{* * *}$ & $4355.874^{* * *}$ & $11.179^{* * *}$ & $-11.822^{* * *}$ \\
\hline Comprehensive insolvency law ind & -0.046 & 0.564 & 0.273 & 0.564 & -0.640 & 0.564 & $3771.580^{* * *}$ & $4200.000^{* * *}$ & $4681.616^{* * *}$ & $92.656^{* * *}$ & $77.244^{* * *}$ \\
\hline Corruption control & -0.504 & -1.419 & -0.853 & -1.419 & -1.183 & -1.419 & $6719.700^{* * *}$ & $6200.000^{* * *}$ & $9898.836^{* * *}$ & $51.295^{* * *}$ & $55.412^{* * *}$ \\
\hline Banking reform & -0.323 & -0.609 & -0.673 & -1.126 & -0.761 & -1.126 & $6196.890^{* * *}$ & $9400.000^{* * *}$ & $10242.499^{* * *}$ & $16.535^{* * *}$ & $-16.890^{* * *}$ \\
\hline
\end{tabular}

Notes : ** and * denote statistical significance at the $1 \%$ and $10 \%$ levels, respectively. Table 2 provides definitions and descriptive statistics of variables. 
Table 4. Determinants of distressed acquisition in 17 European emerging economies: Baseline estimations

\begin{tabular}{|c|c|c|c|c|c|c|}
\hline Model & [1] & [2] & [3] & {$[4]$} & {$[5]$} & {$[6]$} \\
\hline \multicolumn{7}{|l|}{ Firm-specific variables } \\
\hline Joint-stock company & $\begin{array}{l}-0.21597^{* * *} \\
(0.0145)\end{array}$ & $\begin{array}{l}-0.215911^{* * *} \\
(0.0139)\end{array}$ & $\begin{array}{l}-0.07110^{* * *} \\
(0.0129)\end{array}$ & $\begin{array}{l}-0.18106^{* * *} \\
(0.0121)\end{array}$ & $\begin{array}{l}-0.14490^{* * *} \\
(0.0134)\end{array}$ & $\begin{array}{l}-0.07566^{* * *} \\
(0.0129)\end{array}$ \\
\hline Limited liability company & $\begin{array}{l}-0.12009^{\text {*** }} \\
(0.0129)\end{array}$ & $\begin{array}{l}-0.12718^{* * *} \\
(0.0124)\end{array}$ & $\begin{array}{l}-0.04192^{* * *} \\
(0.0109)\end{array}$ & $\begin{array}{l}-0.11594^{* * *} \\
(0.0107)\end{array}$ & $\begin{array}{l}-0.02705^{* *} \\
(0.0114)\end{array}$ & $\begin{array}{l}-0.07267^{* * *} \\
(0.0109)\end{array}$ \\
\hline Large shareholding & $\begin{array}{l}0.69385^{\text {*** }} \\
(0.0120)\end{array}$ & $\begin{array}{l}0.68076^{* * *} \\
(0.0114)\end{array}$ & $\begin{array}{l}0.20150^{* * *} \\
(0.0103)\end{array}$ & $\begin{array}{l}0.70377^{* * *} \\
(0.0100)\end{array}$ & $\begin{array}{l}0.15910^{* * *} \\
(0.0105)\end{array}$ & $\begin{array}{l}0.19389^{* * *} \\
(0.0103)\end{array}$ \\
\hline Foreign ownership & $\begin{array}{l}0.29047^{* * *} \\
(0.0263)\end{array}$ & $\begin{array}{l}0.29811^{* * *} \\
(0.0253)\end{array}$ & $\begin{array}{l}0.01485^{* * *} \\
(0.0213)\end{array}$ & $\begin{array}{l}0.27247^{* * *} \\
(0.0219)\end{array}$ & $\begin{array}{l}0.14152^{* * *} \\
(0.0225)\end{array}$ & $\begin{array}{l}0.05480 \\
(0.0213)\end{array}$ \\
\hline State ownership & $\begin{array}{r}0.02060 \\
(0.0214)\end{array}$ & $\begin{array}{r}0.01236 \\
(0.0208)\end{array}$ & $\begin{array}{l}0.34102^{* * *} \\
(0.0170)\end{array}$ & $\begin{array}{l}0.032533^{*} \\
(0.0178)\end{array}$ & $\begin{array}{l}0.28496^{* * *} \\
(0.0176)\end{array}$ & $\begin{array}{l}0.33562^{* * *} \\
(0.0170)\end{array}$ \\
\hline ROA & $\begin{array}{l}0.02622^{* * *} \\
(0.0014)\end{array}$ & $\begin{array}{l}0.02674^{* * *} \\
(0.0014)\end{array}$ & $\begin{array}{l}0.02485^{* * *} \\
(0.0012)\end{array}$ & $\begin{array}{l}0.02950^{* * *} \\
(0.0012)\end{array}$ & $\begin{array}{l}0.02147^{* * *} \\
(0.0012)\end{array}$ & $\begin{array}{l}0.02502^{* * *} \\
(0.0012)\end{array}$ \\
\hline Liquidity & $\begin{array}{l}0.01672^{* * *} \\
(0.0048)\end{array}$ & $\begin{array}{l}0.013300^{* * *} \\
(0.0046)\end{array}$ & $\begin{array}{l}0.02354^{* * *} \\
(0.0042)\end{array}$ & $\begin{array}{r}0.00528 \\
(0.0041)\end{array}$ & $\begin{array}{l}0.02626^{* * *} \\
(0.0042)\end{array}$ & $\begin{array}{l}0.02505^{* * *} \\
(0.0042)\end{array}$ \\
\hline Solvency & $\begin{array}{l}0.026611^{* * *} \\
(0.0012)\end{array}$ & $\begin{array}{l}0.02820 \text { *** } \\
(0.0011)\end{array}$ & $\begin{array}{l}0.00469^{* * *} \\
(0.0009)\end{array}$ & $\begin{array}{l}0.03252^{* * *} \\
(0.0009)\end{array}$ & $\begin{array}{l}0.00539^{* * *} \\
(0.0010)\end{array}$ & $\begin{array}{l}0.00391 \\
(0.0009)\end{array}$ \\
\hline Labor productivity & $\begin{array}{l}0.00830^{* * *} \\
(0.0008)\end{array}$ & $\begin{array}{l}0.00707^{* * *} \\
(0.0008)\end{array}$ & $\begin{array}{l}0.00485^{* * *} \\
(0.0007)\end{array}$ & $\begin{array}{l}0.00835^{* * *} \\
(0.0007)\end{array}$ & $\begin{array}{r}0.00073 \\
(0.0007)\end{array}$ & $\begin{array}{r}0.00048 \\
(0.0007)\end{array}$ \\
\hline Listed on stock market & $\begin{array}{l}-0.21103^{* * *} \\
(0.0594)\end{array}$ & $\begin{array}{l}-0.18777^{* * *} \\
(0.0565)\end{array}$ & $\begin{array}{l}-0.47812^{* * *} \\
(0.0521)\end{array}$ & $\begin{array}{l}-0.14081^{* * *} \\
(0.0450)\end{array}$ & $\begin{array}{l}-0.42500^{* * *} \\
(0.0534)\end{array}$ & $\begin{array}{l}-0.565511^{* * *} \\
(0.0520)\end{array}$ \\
\hline Firm size & $\begin{array}{l}0.00055^{* * *} \\
(0.0001)\end{array}$ & $\begin{array}{l}0.00050^{* * *} \\
(0.0001)\end{array}$ & $\begin{array}{r}0.00005 \\
(0.0001)\end{array}$ & $\begin{array}{l}0.00047^{* * *} \\
(0.0001)\end{array}$ & $\begin{array}{l}0.00019^{* * *} \\
(0.0001)\end{array}$ & $\begin{array}{l}0.00014^{* *} \\
(0.0001)\end{array}$ \\
\hline Firm age & $\begin{array}{l}-0.00924^{* * *} \\
(0.0030)\end{array}$ & $\begin{array}{l}-0.01326^{* * *} \\
(0.0029)\end{array}$ & $\begin{array}{l}-0.07671^{* * *} \\
(0.0019)\end{array}$ & $\begin{array}{l}-0.02936^{* * *} \\
(0.0023)\end{array}$ & $\begin{array}{l}-0.05675^{* * *} \\
(0.0020)\end{array}$ & $\begin{array}{l}-0.06498^{* * *} \\
(0.0019)\end{array}$ \\
\hline
\end{tabular}

\section{Institutional variables}

Compliance with insolvency law $\quad-0.53154^{* * *}$

(0.0075)

Extensiveness of insolvency law

$-0.55303^{* * *}$

(0.0082)

Enforceability of insolvency law

Comprehensive insolvency law index

$-0.21288$

(0.0068)

$-0.28750^{* * *}$

(0.0041)

Corruption control

$-0.31763^{* * *}$

(0.0059)

Banking reform

\begin{tabular}{|c|c|c|c|c|c|}
\hline & & & & & $\begin{array}{l}-0.24898^{* * *} \\
(0.0067)\end{array}$ \\
\hline Yes & Yes & Yes & Yes & Yes & Yes \\
\hline 211638 & 211638 & 211638 & 211638 & 211638 & 211638 \\
\hline 124460 & 124460 & 124460 & 124460 & 124460 & 124460 \\
\hline 87178 & 87178 & 87178 & 87178 & 87178 & 87178 \\
\hline-166502.100 & -166796.100 & -170051.400 & -166966.400 & -168855.500 & -169831.400 \\
\hline $16660.800^{* * *}$ & $17034.900^{* * *}$ & $6382.760^{* * *}$ & $20170.130^{* * *}$ & $7820.910^{* * *}$ & $6711.520^{* * *}$ \\
\hline-0.730 & -0.772 & 0.965 & -0.903 & 0.937 & 0.965 \\
\hline $474.93^{* * *}$ & $510.02^{* * *}$ & $2801.74^{* * *}$ & $981.39^{* * *}$ & $3357.55^{* * *}$ & $3242.08^{* * *}$ \\
\hline
\end{tabular}

NACE division-level fixed effects

$\mathrm{N}$
Censored observations

Uncensored observations

Log likelihood

Wald test $\left(\chi^{2}\right)$

$\rho$

LR test $\left(\chi^{2}\right)$

$-0.730$

Notes : This table contains estimation results of a Heckman probit model with a sample selection of the determinants of distressed acquisition. The coefficient of a constant term is omitted from the table. The estimation results of the first stage are reported in Appendix Table A3. Table 2 provides detailed definitions and descriptive statistics of the independent variables used in the estimation. Figures in parentheses are robust standard errors. The Wald test examines the null hypothesis that all coefficients are zero. The LR test of independence of equations examines the null hypothesis that $=0 . * * *, * *$, and $*$ denote statistical significance at the $1 \%, 5 \%$, and $10 \%$ levels, respectively. 
Table 5. Determinants of distressed acquisition: Estimation by industry

\begin{tabular}{|c|c|c|c|c|c|c|c|c|c|c|c|c|c|c|c|}
\hline \multirow{2}{*}{$\begin{array}{l}\text { Target industry } \\
\text { Model }\end{array}$} & \multicolumn{3}{|c|}{ Agriculture, forestry, and fishing (Section A) } & \multicolumn{3}{|c|}{ Mining, energy, and manufacturing (Sections B-E) } & \multicolumn{3}{|c|}{ Construction (Section F) } & \multicolumn{3}{|c|}{ Nonfinancial services (Sections G-J, L-S) } & \multicolumn{3}{|c|}{ Financial services (Section K) } \\
\hline & [1] & [2] & [3] & [4] & [5] & [6] & [7] & [8] & [9] & [10] & [11] & [12] & [13] & [14] & [15] \\
\hline \multicolumn{16}{|l|}{ Firm-specific variables } \\
\hline Joint-stock company & $\begin{array}{l}-0.04157 \\
(0.0562)\end{array}$ & $\begin{array}{l}-0.10027^{* *} \\
(0.0480)\end{array}$ & $\begin{array}{r}-0.06737 \\
(0.0500)\end{array}$ & $\begin{array}{l}-0.13871^{* * *} \\
(0.0190)\end{array}$ & $\begin{array}{l}-0.03261 \\
(0.0249)\end{array}$ & $\begin{array}{l}-0.049722^{* *} \\
(0.0238)\end{array}$ & $\begin{array}{l}-0.21858^{* * * *} \\
(0.0316)\end{array}$ & $\begin{array}{l}-0.209722^{* * *} \\
(0.0401)\end{array}$ & $\begin{array}{l}-0.07173{ }^{*} \\
(0.0377)\end{array}$ & $\begin{array}{l}-0.17246^{* * *} \\
(0.0184)\end{array}$ & $\begin{array}{l}-0.22369^{* * * *} \\
(0.0198)\end{array}$ & $\begin{array}{l}-0.156566^{* * *} \\
(0.0191)\end{array}$ & $\begin{array}{l}-0.20420 \\
(0.1949)\end{array}$ & $\begin{array}{r}-0.25141 \\
(0.1531)\end{array}$ & $\begin{array}{r}-0.24603 \\
(0.1589)\end{array}$ \\
\hline Limited liability company & $\begin{array}{l}0.12233^{* *} \\
(0.0503)\end{array}$ & $\begin{array}{l}0.18244 \\
(0.0405)\end{array}$ & $\begin{array}{l}0.22920 \\
(0.0424)\end{array}$ & $\begin{array}{l}0.01037 \\
(0.0179)\end{array}$ & $\begin{array}{l}0.144699^{\cdots *} \\
(0.0224)\end{array}$ & $\begin{array}{l}0.18236{ }^{\cdots \cdots *} \\
(0.0214)\end{array}$ & $\begin{array}{l}-0.19157^{* \cdots *} \\
(0.0279)\end{array}$ & $\begin{array}{r}-0.01153 \\
(0.0343)\end{array}$ & $\begin{array}{l}-0.10412{ }^{* *} \\
(0.0316)\end{array}$ & $\begin{array}{l}-0.13210^{* * * *} \\
(0.0157)\end{array}$ & $\begin{array}{l}-0.071300^{\cdots \cdots} \\
(0.0163)\end{array}$ & $\begin{array}{r}-0.02039 \\
(0.0155)\end{array}$ & $\begin{array}{l}-0.36765^{*} \\
(0.1999)\end{array}$ & $\begin{array}{l}-0.43817{ }^{\cdots \cdots} \\
(0.1580)\end{array}$ & $\begin{array}{l}-0.43688^{\cdots \cdots *} \\
(0.1642)\end{array}$ \\
\hline Large shareholding & $\begin{array}{l}0.718777^{\cdots \cdots *} \\
(0.0499)\end{array}$ & $\begin{array}{l}0.03904 \\
(0.0405)\end{array}$ & $\begin{array}{l}0.03130 \\
(0.0522)\end{array}$ & $\begin{array}{l}0.73262{ }^{\cdots * *} \\
(0.0169)\end{array}$ & $\begin{array}{l}0.20774 \cdots \\
(0.0210)\end{array}$ & $\begin{array}{l}0.228733^{\cdots \cdots} \\
(0.0206)\end{array}$ & $\begin{array}{l}0.71043^{\cdots * *} \\
(0.0260)\end{array}$ & $\begin{array}{l}0.19075 \\
(0.0284)\end{array}$ & $\begin{array}{l}0.22858 \\
(0.0280)\end{array}$ & $\begin{array}{l}0.69754^{* \cdots *} \\
(0.0147)\end{array}$ & $\begin{array}{l}0.14731{ }^{\cdots \cdots} \\
(0.0147)\end{array}$ & $\begin{array}{l}0.190055^{* \cdots *} \\
(0.0145)\end{array}$ & $\begin{array}{l}0.53788^{\cdots * *} \\
(0.1618)\end{array}$ & $\begin{array}{l}0.12581 \\
(0.1111)\end{array}$ & $\begin{array}{l}0.16042 \\
(0.1187)\end{array}$ \\
\hline Foreign ownership & $\begin{array}{l}0.304988^{* *} \\
(0.1531)\end{array}$ & $\begin{array}{l}0.50237^{* \cdots *} \\
(0.1300)\end{array}$ & $\begin{array}{l}0.46820^{\circ * *} \\
(0.1354)\end{array}$ & $\begin{array}{l}0.24351 \\
(0.0304)\end{array}$ & $\begin{array}{l}0.07935 \\
(0.0372)\end{array}$ & $\begin{array}{l}0.00672 \\
(0.0348)\end{array}$ & $\begin{array}{l}0.16210^{*} \\
(0.0931)\end{array}$ & $\begin{array}{l}0.18448 \\
(0.1163)\end{array}$ & $\begin{array}{l}0.02379 \\
(0.1115)\end{array}$ & $\begin{array}{l}0.22300^{* * * *} \\
(0.0318)\end{array}$ & $\begin{array}{l}0.18116{ }^{* * *} \\
(0.0318)\end{array}$ & $\begin{array}{l}0.09617^{* * *} \\
(0.0304)\end{array}$ & $\begin{array}{l}0.04131 \\
(0.2173)\end{array}$ & $\begin{array}{l}0.01673 \\
(0.1715)\end{array}$ & $\begin{array}{l}-0.03919 \\
(0.1803)\end{array}$ \\
\hline State ownership & $\begin{array}{l}0.00652 \\
(0.0849)\end{array}$ & $\begin{array}{l}0.16518^{* *} \\
(0.0696)\end{array}$ & $\begin{array}{l}0.15996^{* *} \\
(0.0737)\end{array}$ & $\begin{array}{l}0.01309 \\
(0.0280)\end{array}$ & $\begin{array}{l}0.33163^{* * *} \\
(0.0320)\end{array}$ & $\begin{array}{l}0.37859^{* * *} \\
(0.0307)\end{array}$ & $\begin{array}{l}0.00655 \\
(0.0563)\end{array}$ & $\begin{array}{l}0.52296^{* * *} \\
(0.0576)\end{array}$ & $\begin{array}{l}0.58299^{* * *} \\
(0.0561)\end{array}$ & $\begin{array}{l}0.13234^{* * *} \\
(0.0263)\end{array}$ & $\begin{array}{l}0.28328^{* * *} \\
(0.0246)\end{array}$ & $\begin{array}{l}0.34320^{* * *} \\
(0.0238)\end{array}$ & $\begin{array}{r}-0.08569 \\
(0.2318)\end{array}$ & $\begin{array}{l}0.04243 \\
(0.1844)\end{array}$ & $\begin{array}{l}0.05290 \\
(0.1906)\end{array}$ \\
\hline ROA & $\begin{array}{l}0.04824 \\
(0.0086)\end{array}$ & $\begin{array}{l}0.02770 \\
(0.0060)\end{array}$ & $\begin{array}{l}0.02179^{\circ * *} \\
(0.0068)\end{array}$ & $\begin{array}{l}0.03881^{* * *} \\
(0.0021)\end{array}$ & $\begin{array}{l}0.01984 \\
(0.0026)\end{array}$ & $\begin{array}{l}0.02287^{\cdots *} \\
(0.0025)\end{array}$ & $\begin{array}{l}-0.02098^{* * *} \\
(0.0031)\end{array}$ & $\begin{array}{l}-0.01280^{\cdots *} \\
(0.0036)\end{array}$ & $\begin{array}{l}-0.019877^{* * *} \\
(0.0035)\end{array}$ & $\begin{array}{l}0.02287^{* * *} \\
(0.0017)\end{array}$ & $\begin{array}{l}0.02104 \\
(0.0017)\end{array}$ & $\begin{array}{l}0.02402^{* * *} \\
(0.0017)\end{array}$ & $\begin{array}{l}0.00153 \\
(0.0182)\end{array}$ & $\begin{array}{l}-0.02559^{\circ "} \\
(0.0127)\end{array}$ & $\begin{array}{l}-0.026577^{* *} \\
(0.0129)\end{array}$ \\
\hline Liquidity & $\begin{array}{l}0.04806 \text { "* } \\
(0.0213)\end{array}$ & $\begin{array}{l}-0.02021 \\
(0.0176)\end{array}$ & $\begin{array}{l}-0.02300 \\
(0.0190)\end{array}$ & $\begin{array}{l}0.014688^{*} \\
(0.0082)\end{array}$ & $\begin{array}{l}0.03908 \cdots \\
(0.0096)\end{array}$ & $\begin{array}{l}0.03755^{\circ \cdots} \\
(0.0093)\end{array}$ & $\begin{array}{l}0.02125^{*} \\
(0.0127)\end{array}$ & $\begin{array}{l}0.02330 \\
(0.0148)\end{array}$ & $\begin{array}{l}0.01801 \\
(0.0146)\end{array}$ & $\begin{array}{l}0.02212 \\
(0.0056)\end{array}$ & $\begin{array}{l}0.033799^{\cdots \cdots} \\
(0.0056)\end{array}$ & $\begin{array}{l}0.03409^{\cdots \cdots *} \\
(0.0055)\end{array}$ & $\begin{array}{l}0.04175^{*} \\
(0.0233)\end{array}$ & $\begin{array}{l}0.03237^{*} \\
(0.0192)\end{array}$ & $\begin{array}{l}0.03451^{*} \\
(0.0197)\end{array}$ \\
\hline Solvency & $\begin{array}{l}0.03156^{* * *} \\
(0.0047)\end{array}$ & $\begin{array}{l}-0.00337 \\
(0.0038)\end{array}$ & $\begin{array}{l}0.00265 \\
(0.0043)\end{array}$ & $\begin{array}{l}0.04416{ }^{* * * *} \\
(0.0016)\end{array}$ & $\begin{array}{l}0.00321^{*} \\
(0.0019)\end{array}$ & $\begin{array}{l}0.00355^{*} \\
(0.0018)\end{array}$ & $\begin{array}{l}0.037622^{* * *} \\
(0.0026)\end{array}$ & $\begin{array}{l}-0.00097 \\
(0.0031)\end{array}$ & $\begin{array}{l}0.00357 \\
(0.0030)\end{array}$ & $\begin{array}{l}0.03159^{* * *} \\
(0.0014)\end{array}$ & $\begin{array}{l}0.00914{ }^{\cdots *} \\
(0.0013)\end{array}$ & $\begin{array}{l}0.00760^{* * *} \\
(0.0013)\end{array}$ & $\begin{array}{l}-0.01815 \\
(0.0112)\end{array}$ & $\begin{array}{l}-0.02273{ }^{\cdots *} \\
(0.0086)\end{array}$ & $\begin{array}{l}-0.022133^{*} \\
(0.0088)\end{array}$ \\
\hline Labor productivity & $\begin{array}{c}-0.00862 \\
(0.0072)\end{array}$ & $\begin{array}{l}-0.03992^{2 * *} \\
(0.0062)\end{array}$ & $\begin{array}{l}-0.05968^{* * *} \\
(0.0067)\end{array}$ & $\begin{array}{l}0.011799^{* * *} \\
(0.0014)\end{array}$ & $\begin{array}{l}0.003977^{* * *} \\
(0.0016)\end{array}$ & $\begin{array}{l}0.00238 \\
(0.0015)\end{array}$ & $\begin{array}{l}0.00402^{*} \\
(0.0022)\end{array}$ & $\begin{array}{l}0.00150 \\
(0.0027)\end{array}$ & $\begin{array}{l}0.00137 \\
(0.0027)\end{array}$ & $\begin{array}{l}0.00670{ }^{* * *} \\
(0.0009)\end{array}$ & $\begin{array}{l}0.00137 \\
(0.0009)\end{array}$ & $\begin{array}{l}0.00022 \\
(0.0008)\end{array}$ & $\begin{array}{l}-0.00857 \\
(0.0062)\end{array}$ & $\begin{array}{c}-0.00470 \\
(0.0050)\end{array}$ & $\begin{array}{r}-0.00609 \\
(0.0053)\end{array}$ \\
\hline Listed on stock market & $\begin{array}{l}0.00534 \\
(0.4243)\end{array}$ & $\begin{array}{r}-0.32920 \\
(0.3824)\end{array}$ & $\begin{array}{l}-0.74428^{*} \\
(0.3972)\end{array}$ & $\begin{array}{l}-0.13815^{* * *} \\
(0.0470)\end{array}$ & $\begin{array}{l}-0.37861^{* * *} \\
(0.0689)\end{array}$ & $\begin{array}{l}-0.491211^{* * *} \\
(0.0670)\end{array}$ & $\begin{array}{l}-0.01861 \\
(0.1282)\end{array}$ & $\begin{array}{l}-0.73676^{* * *} \\
(0.2406)\end{array}$ & $\begin{array}{l}-0.92427^{* * *} \\
(0.2365)\end{array}$ & $\begin{array}{r}-0.04595 \\
(0.0918)\end{array}$ & $\begin{array}{l}-0.535355^{* * *} \\
(0.1076)\end{array}$ & $\begin{array}{l}-0.675277^{* * * *} \\
(0.1031)\end{array}$ & $\begin{array}{l}0.14044 \\
(0.4594)\end{array}$ & $\begin{array}{l}0.06074 \\
(0.3562)\end{array}$ & $\begin{array}{l}0.02905 \\
(0.3658)\end{array}$ \\
\hline Firm size & $\begin{array}{l}0.00012 \\
(0.0005)\end{array}$ & $\begin{array}{l}-0.00081^{*} \\
(0.0004)\end{array}$ & $\begin{array}{c}-0.00084^{*} \\
(0.0004)\end{array}$ & $\begin{array}{l}0.00038^{* * *} \\
(0.0001)\end{array}$ & $\begin{array}{l}0.000311^{* * *} \\
(0.0001)\end{array}$ & $\begin{array}{l}0.000255^{* * *} \\
(0.0001)\end{array}$ & $\begin{array}{r}-0.00004 \\
(0.0002)\end{array}$ & $\begin{array}{l}-0.00058^{* *} \\
(0.0003)\end{array}$ & $\begin{array}{l}-0.00063^{* *} \\
(0.0003)\end{array}$ & $\begin{array}{l}0.00065^{* * *} \\
(0.0001)\end{array}$ & $\begin{array}{l}0.000244^{* * *} \\
(0.0001)\end{array}$ & $\begin{array}{l}0.00011^{* *} \\
(0.0001)\end{array}$ & $\begin{array}{l}0.00012 \\
(0.0005)\end{array}$ & $\begin{array}{l}-0.000688^{*} \\
(0.0004)\end{array}$ & $\begin{array}{l}-0.00071^{*} \\
(0.0004)\end{array}$ \\
\hline Firm age & $\begin{array}{l}-0.02650{ }^{* *} \\
(0.0107)\end{array}$ & $\begin{array}{l}-0.04858^{* * *} \\
(0.0082)\end{array}$ & $\begin{array}{l}-0.065010^{* * *} \\
(0.0087)\end{array}$ & $\begin{array}{l}-0.01483^{* * *} \\
(0.0028)\end{array}$ & $\begin{array}{l}-0.03428{ }^{* * *} \\
(0.0034)\end{array}$ & $\begin{array}{l}-0.040022^{* * *} \\
(0.0033)\end{array}$ & $\begin{array}{l}-0.01907{ }^{* * *} \\
(0.0059)\end{array}$ & $\begin{array}{l}-0.0707{ }^{* * *} \\
(0.0062)\end{array}$ & $\begin{array}{l}-0.08217{ }^{* * *} \\
(0.0060)\end{array}$ & $\begin{array}{l}-0.05266{ }^{* * *} \\
(0.0039)\end{array}$ & $\begin{array}{l}-0.07214^{* * *} \\
(0.0030)\end{array}$ & $\begin{array}{l}-0.08330^{* * *} \\
(0.0029)\end{array}$ & $\begin{array}{l}-0.02842 \\
(0.0290)\end{array}$ & $\begin{array}{l}-0.05444{ }^{* *} \\
(0.0224)\end{array}$ & $\begin{array}{l}-0.056599^{* *} \\
(0.0229)\end{array}$ \\
\hline \multicolumn{16}{|l|}{ Institutional variables } \\
\hline Comprehensive insolvency law index & $\begin{array}{l}-0.35739^{* * *} \\
(0.0148)\end{array}$ & & & $\begin{array}{l}-0.20376^{* * * *} \\
(0.0057)\end{array}$ & & & $\begin{array}{l}-0.31225^{* * *} \\
(0.0095)\end{array}$ & & & $\begin{array}{l}-0.28643^{* * * *} \\
(0.0064)\end{array}$ & & & $\begin{array}{l}-0.310988^{* * *} \\
(0.0650)\end{array}$ & & \\
\hline Corruption control & & $\begin{array}{l}-0.40799^{* * *} \\
(0.0367)\end{array}$ & & & $\begin{array}{l}-0.27386^{* * *} \\
(0.0098)\end{array}$ & & & $\begin{array}{l}-0.428866^{* * *} \\
(0.0191)\end{array}$ & & & $\begin{array}{l}-0.32107^{* * * *} \\
(0.0088)\end{array}$ & & & $\begin{array}{r}-0.04165 \\
(0.0691)\end{array}$ & \\
\hline Banking reform & & & $\begin{array}{l}-0.11040^{* *} \\
(0.0562)\end{array}$ & & & $\begin{array}{l}-0.230433^{* * *} \\
(0.0116)\end{array}$ & & & $\begin{array}{l}-0.300355^{* * *} \\
(0.0197)\end{array}$ & & & $\begin{array}{l}-0.23937^{7 * *} \\
(0.0099)\end{array}$ & & & $\begin{array}{l}0.08454 \\
(0.1101)\end{array}$ \\
\hline NACE division-level fixed effects & Yes & Yes & Yes & Yes & Yes & Yes & Yes & Yes & Yes & Yes & Yes & Yes & Yes & Yes & Yes \\
\hline $\mathrm{N}$ & 15208 & 15208 & 15208 & 60370 & 60370 & 60370 & 25882 & 25882 & 25882 & 108192 & 108192 & 108192 & 1986 & 1986 & 1986 \\
\hline Censored observations & 10314 & 10314 & 10314 & 39246 & 39246 & 39246 & 13114 & 13114 & 13114 & 60822 & 60822 & 60822 & 1022 & 1022 & 1022 \\
\hline Uncensored observations & 4894 & 4894 & 4894 & 21124 & 21124 & 21124 & 12768 & 12768 & 12768 & 47370 & 47370 & 47370 & 964 & 964 & 964 \\
\hline Log likelihood & -10515.640 & -10643.160 & -10703.950 & -43477.620 & -44174.250 & -44405.840 & -21255.330 & -21355.550 & -21555.890 & -87828.600 & -88798.520 & -89270.090 & -1760.152 & -1774.855 & -1774.716 \\
\hline Wald test $\left(\chi^{2}\right)$ & $1276.74^{* * * *}$ & $454.17 \cdots$ & $343.15^{* * *}$ & $6118.32^{* * * *}$ & $1587.65^{* * *}$ & $1263.34 * *$ & $2715.02^{* * *}$ & $1065.07^{* * *}$ & $856.42 \cdots$ & $10167.95^{* * * *}$ & $4248.98^{\circ * *}$ & $3783.07^{* * *}$ & $58.19^{* * * *}$ & $36.82 * * *$ & $35.18 * *$ \\
\hline$\rho$ & -0.553 & 0.869 & 0.778 & -0.971 & 0.923 & 0.967 & -0.961 & 0.953 & 0.980 & -0.888 & 0.931 & 0.959 & 0.185 & 0.876 & 0.818 \\
\hline LR test $\left(\chi^{2}\right)$ & $21.40^{* * *}$ & $199.96^{* * *}$ & $48.50^{* * *}$ & $584.05^{n * *}$ & $545.51^{* * *}$ & $521.12^{* * *}$ & $83.69^{* * *}$ & $693.89^{* *}$ & $792.65^{* * *}$ & $406.92^{\cdots *}$ & $1411.78^{* \cdots *}$ & $1274.97^{\text {**** }}$ & 0.32 & $26.55^{* * * *}$ & $14.75^{* * *}$ \\
\hline
\end{tabular}

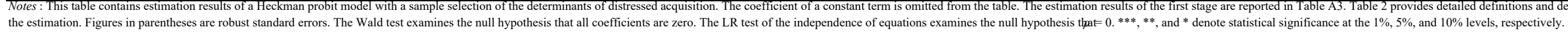


Table 6. Determinants of distressed acquisition: Estimation by year focusing on the impacts of country-level institutional factors

\begin{tabular}{|c|c|c|c|c|c|c|c|c|c|c|c|c|c|}
\hline Observation year & 2007 & 2008 & 2009 & 2010 & 2011 & 2012 & 2013 & 2014 & 2015 & 2016 & 2017 & 2018 & 2019 \\
\hline Comprehensive insolvency law index & $\begin{array}{l}0.12944^{* * *} \\
(0.0071)\end{array}$ & $\begin{array}{l}0.016711^{* * *} \\
(0.0053)\end{array}$ & $\begin{array}{r}-0.00142 \\
(0.0043)\end{array}$ & $\begin{array}{l}-0.06188^{* * *} \\
(0.0046)\end{array}$ & $\begin{array}{l}-0.11534^{* * *} \\
(0.0046)\end{array}$ & $\begin{array}{l}-0.149511^{* * *} \\
(0.0046)\end{array}$ & $\begin{array}{l}-0.13066^{* * *} \\
(0.0047)\end{array}$ & $\begin{array}{l}-0.22305^{* * *} \\
(0.0026)\end{array}$ & $\begin{array}{l}-0.13614^{* * *} \\
(0.0033)\end{array}$ & $\begin{array}{l}-0.058000^{* * *} \\
(0.0065)\end{array}$ & $\begin{array}{l}-0.02587^{\text {*** }} \\
(0.0066)\end{array}$ & $\begin{array}{l}-0.03065^{* * *} \\
(0.0031)\end{array}$ & $\begin{array}{r}-0.00417 \\
(0.0069)\end{array}$ \\
\hline Corruption control & $\begin{array}{r}-0.01212 \\
(0.0174)\end{array}$ & $\begin{array}{l}-0.10252^{* * *} \\
(0.0115)\end{array}$ & $\begin{array}{l}-0.13400^{* * *} \\
(0.0098)\end{array}$ & $\begin{array}{l}-0.17503^{* * *} \\
(0.0111)\end{array}$ & $\begin{array}{l}-0.32269^{* * *} \\
(0.0112)\end{array}$ & $\begin{array}{l}-0.24347^{* * *} \\
(0.0084)\end{array}$ & $\begin{array}{l}-0.17058^{* * *} \\
(0.0084)\end{array}$ & $\begin{array}{l}-0.26745^{* * *} \\
(0.0073)\end{array}$ & $\begin{array}{l}-0.19735^{* * *} \\
(0.0089)\end{array}$ & $\begin{array}{l}-0.05242^{* * *} \\
(0.0039)\end{array}$ & $\begin{array}{l}0.04413^{* * *} \\
(0.0066)\end{array}$ & $\begin{array}{l}0.04396^{* * *} \\
(0.0082)\end{array}$ & $\begin{array}{l}0.01505^{* *} \\
(0.0066)\end{array}$ \\
\hline Banking reform & $\begin{array}{l}-0.24579^{* * *} \\
(0.0208)\end{array}$ & $\begin{array}{l}-0.14333^{* * *} \\
(0.0168)\end{array}$ & $\begin{array}{l}-0.146600^{* * *} \\
(0.0130)\end{array}$ & $\begin{array}{l}-0.05032^{* * *} \\
(0.0132)\end{array}$ & $\begin{array}{l}-0.20292^{* * *} \\
(0.0141)\end{array}$ & $\begin{array}{l}-0.24309^{* * *} \\
(0.0130)\end{array}$ & $\begin{array}{l}-0.20032^{* * *} \\
(0.0143)\end{array}$ & $\begin{array}{l}-0.08070{ }^{* * *} \\
(0.0115)\end{array}$ & $\begin{array}{l}-0.19445^{* * *} \\
(0.0139)\end{array}$ & $\begin{array}{l}0.05468 \\
(0.0049)\end{array}$ & $\begin{array}{l}0.04188^{* * *} \\
(0.0083)\end{array}$ & $\begin{array}{l}0.018811^{* *} \\
(0.0089)\end{array}$ & $\begin{array}{l}0.01259 \\
(0.0087)\end{array}$ \\
\hline $\mathrm{N}$ & 211645 & 210335 & 206935 & 201731 & 195669 & 188487 & 179305 & 170416 & 159046 & 146815 & 137653 & 131655 & 127647 \\
\hline Censored observations & 210335 & 206935 & 201731 & 195669 & 188487 & 179305 & 170416 & 159046 & 146815 & 137653 & 131655 & 127647 & 124460 \\
\hline Uncensored observations & 1310 & 3400 & 5204 & 6062 & 7182 & 9182 & 8889 & 11370 & 12231 & 9162 & 5998 & 4008 & 3187 \\
\hline
\end{tabular}


Appendix Figure A1. Distribution of sample firms in terms of number of employees, total turnover, total assets, and industries

(a) Number of employees

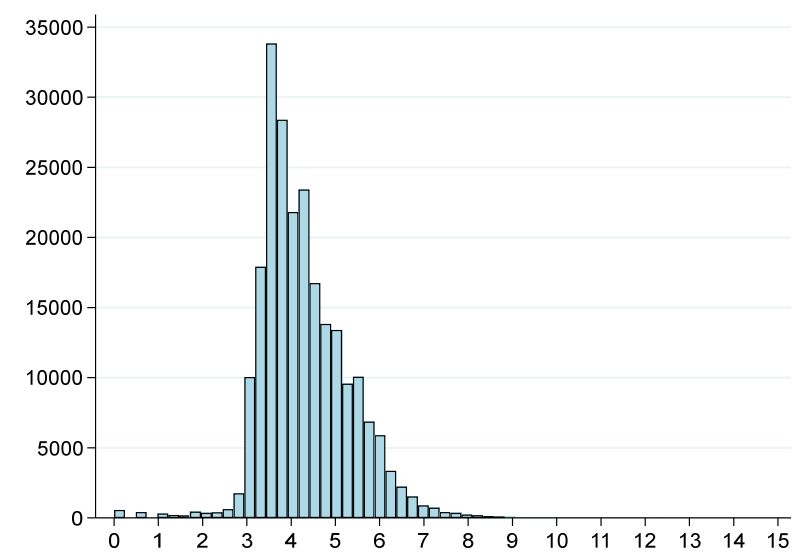

(c) Total assets

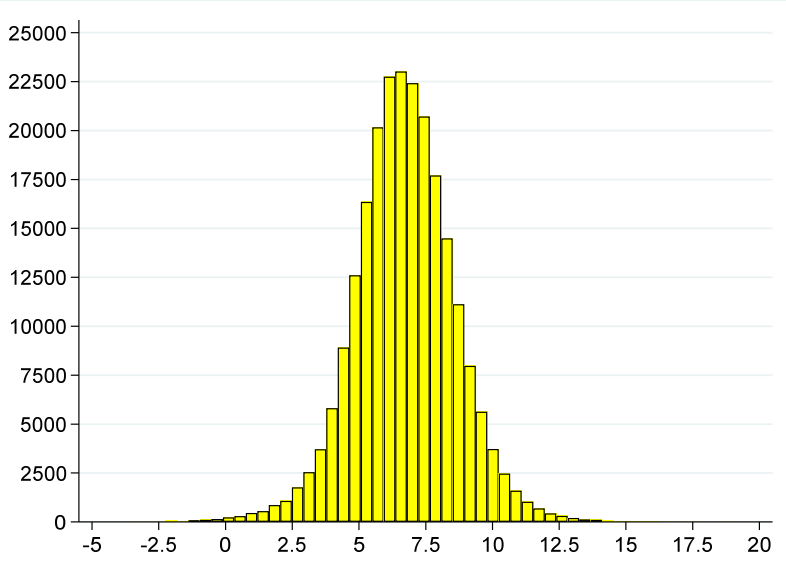

(b) Total turnover

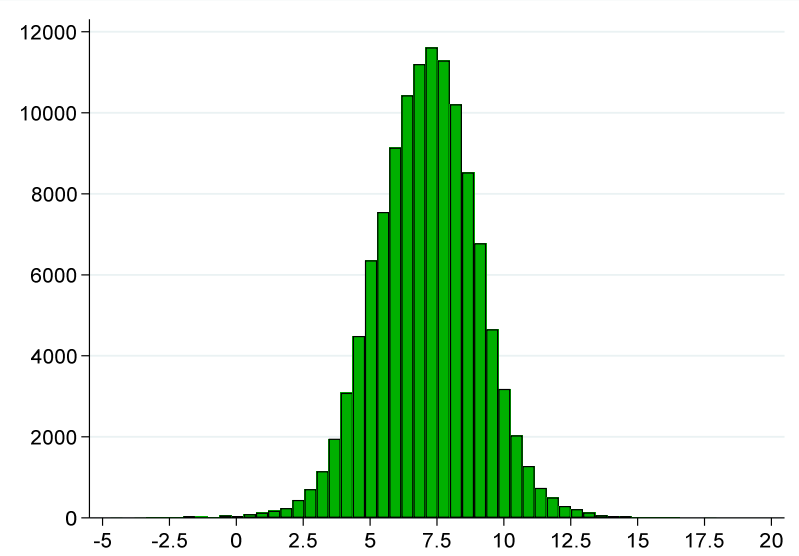

(d) Industries

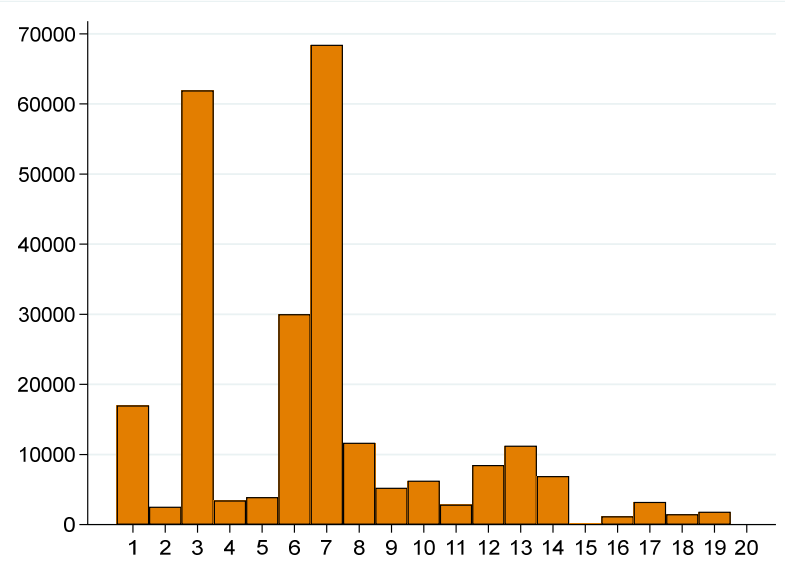

Notes: The vertical axis is the number of firms. In Panels (a), (b), and (c), the horizontal axis is the natural logarithm of the variable concerned. In Panel (d), the horizontal axis takes a value of 1 for agriculture, forestry, and fishing; 2 for mining and quarrying; 3 for manufacturing; 4 for electricity, gas, steam, and air conditioning supply; 5 for water supply, sewerage, waste management, and remediation activities; 6 for construction; 7 for wholesale and retail trade and repair of motor vehicles and motorcycles; 8 for transportation and storage; 9 for accommodation and food service activities; 10 for information and communication; 11 for financial and insurance activities; 12 for real estate activities; 13 for professional, scientific, and technical activities; 14 for administrative and support service activities; 15 for public administration and defense, compulsory social security; 16 for education; 17 for human health and social work activities; 18 for arts, entertainment, and recreation; 19 for other service activities; and 20 for activities of households as employers and undifferentiated goods- and services-producing activities of households for own use, according to the NACE industrial classification. 
Appendix Figure A2. Original country score of the EBRD insolvency indices

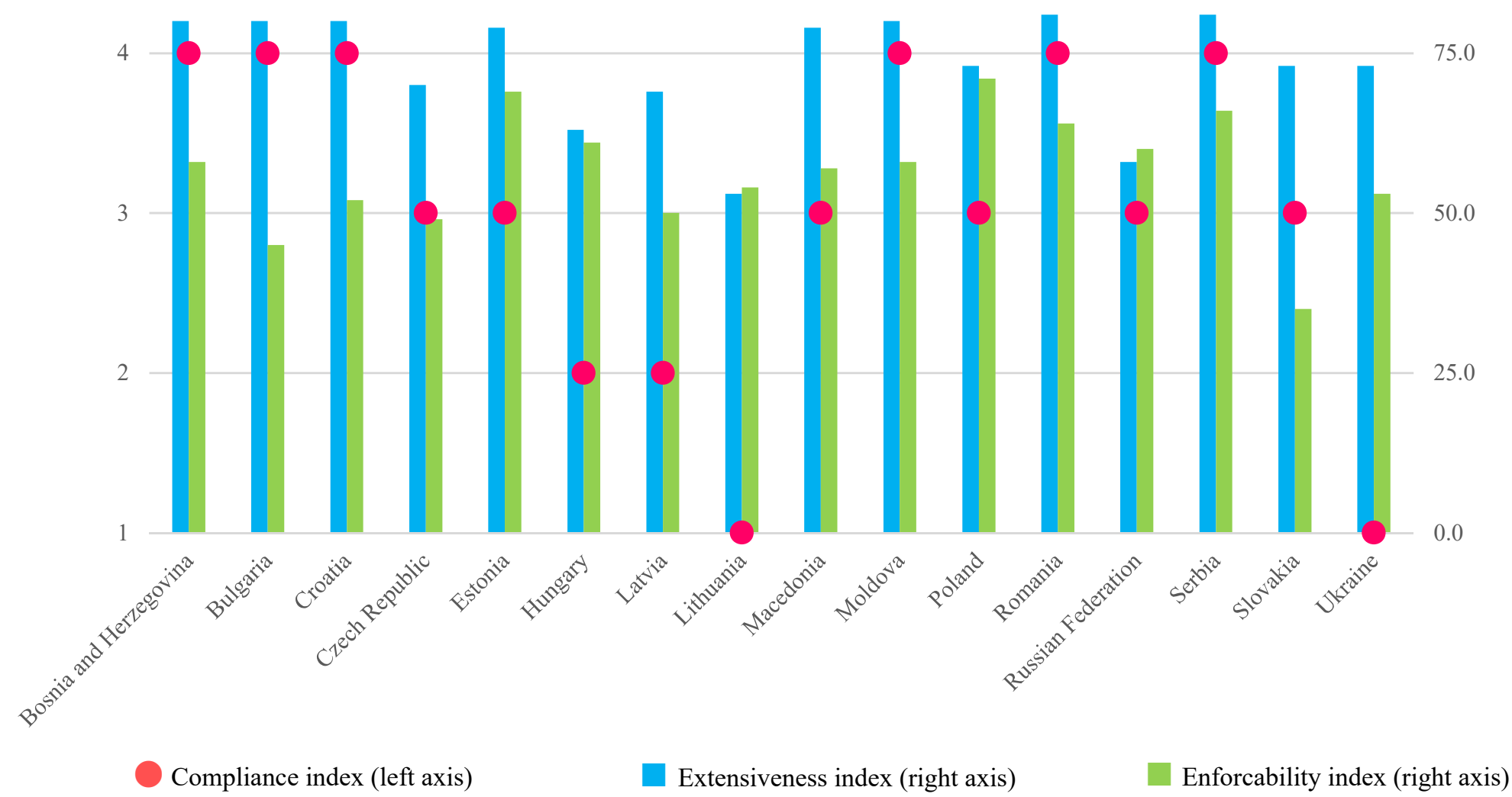

Note : Each value on the left axis denotes the followings: 1: very low conpliance with international standards; 2 : low compliance; 3 : medium compliance; 4 : high compliance; 5 : very high compliance. 
Appendix Table A1. Correlation matrix of variables used in empirical analysis

\begin{tabular}{|c|c|c|c|c|c|c|c|c|c|}
\hline $\begin{array}{l}\text { Joint-stock } \\
\text { company }\end{array}$ & $\begin{array}{l}\text { Limited } \\
\text { liability } \\
\text { company }\end{array}$ & $\begin{array}{c}\text { Large } \\
\text { shareholding }\end{array}$ & $\begin{array}{c}\text { Foreign } \\
\text { ownership }\end{array}$ & $\begin{array}{c}\text { State } \\
\text { ownership }\end{array}$ & Board size & $\begin{array}{l}\text { International } \\
\text { audit firm }\end{array}$ & ROA & Liquidity & Solvency \\
\hline
\end{tabular}

\section{Joint-stock company}

Limited liability company

Large shareholding

Foreign ownership

State ownership

Board size

International audit firm

ROA

Liquidity

Solvency

Labor productivity

Listed on stock market

Firm size

Firm age

Compliance with insolvency law

Extensiveness of insolvency law

Enforceability of insolvency law

Comprehensive insolvency law index

Corruption control

Banking reform
1.000

$-0.546$

$-0.009$

$\begin{array}{ll}-0.027 & 0.002\end{array}$

0.059

0.277

$-0.180$

$-0.272$

0.018

$-0.048$

0.025

0.079

$-0.019$

0.197

0.084

0.199

$-0.013$

$-0.006$

$-0.095$

0.011

$-0.120$

$-0.114$

1.000

$0.137 \quad 1.000$

$0.102 \quad 1.000$

$0.114 \quad-0.048$

1.000

$0.039 \quad 0.079$

0.062

$-0.003$

1.000

$\begin{array}{lll}-0.008 & 0.035 & 0.210\end{array}$

$0.125 \quad 0.002$

$-0.042$

0.107

1.000

$0.075 \quad 0.125$

0.030

0.002

$-0.034$

0.009

0.022

0.023

0.091

0.087

0.023

$-0.047$

0.086

0.159

0.015

0.209

0.028

0.244

0.223

0.223

0.061

$0.092 \quad-0.005$

$-0.059$

$-0.050$

0.076

$-0.001$

$-0.078$

0.232

0.033

$-0.035$

0.031

$-0.009$

$-0.081$

0.223

0.190

$-0.060$

0.196

0.165

$-0.029$

1.000

0.268

1.000

0.366

0.441

1.000

0.095

0.028

$-0.022$

$-0.063$

$-0.005$

0.062

$-0.053$

0.031

0.031

$-0.016$

0.029

0.254

0.080

$-0.010$

$-0.085$

0.082

$-0.016$

$-0.088$

$-0.052$

0.025

0.053

$\begin{array}{lll}0.086 & -0.017 & -0.091\end{array}$

$-0.117 \quad 0.135$

(2)

.

.




\begin{tabular}{|c|c|c|c|c|c|c|c|c|c|c|}
\hline & $\begin{array}{c}\text { Labor } \\
\text { productivity }\end{array}$ & $\begin{array}{c}\text { Listed on } \\
\text { stock market }\end{array}$ & Firm size & Firm age & $\begin{array}{c}\text { Compliance } \\
\text { with } \\
\text { insolvency } \\
\text { law } \\
\end{array}$ & $\begin{array}{c}\text { Extensiveness } \\
\text { of insolvency } \\
\text { law }\end{array}$ & $\begin{array}{c}\text { Enforceability } \\
\text { of insolvency } \\
\text { law }\end{array}$ & $\begin{array}{c}\text { Comprehensi } \\
\text { ve insolvency } \\
\text { law index }\end{array}$ & $\begin{array}{l}\text { Corruption } \\
\text { control }\end{array}$ & $\begin{array}{l}\text { Banking } \\
\text { reform }\end{array}$ \\
\hline Labor productivity & 1.000 & & & & & & & & & \\
\hline Listed on stock market & -0.016 & 1.000 & & & & & & & & \\
\hline Firm size & 0.332 & 0.134 & 1.000 & & & & & & & \\
\hline Firm age & 0.071 & 0.163 & 0.170 & 1.000 & & & & & & \\
\hline Compliance with insolvency law & 0.113 & 0.129 & 0.042 & 0.078 & 1.000 & & & & & \\
\hline Extensiveness of insolvency law & 0.069 & 0.131 & 0.023 & 0.066 & 0.984 & 1.000 & & & & \\
\hline Enforceability of insolvency law & 0.062 & -0.025 & 0.041 & 0.082 & -0.209 & -0.261 & 1.000 & & & \\
\hline Comprehensive insolvency law index & 0.074 & 0.127 & 0.022 & 0.051 & 0.971 & 0.982 & -0.423 & 1.000 & & \\
\hline Corruption control & 0.210 & 0.018 & 0.114 & 0.221 & 0.273 & 0.232 & 0.579 & 0.119 & 1.000 & \\
\hline Banking reform & 0.264 & -0.061 & 0.139 & 0.202 & -0.039 & -0.099 & 0.763 & -0.219 & 0.860 & 1.000 \\
\hline
\end{tabular}

Note: For sources, definitions, and descriptive statistics of the variables, see Table 2. 
Appendix Table A2. Estimation results of the principal component analysis of insolvency law variables

\begin{tabular}{|c|c|c|c|c|c|}
\hline \multicolumn{4}{|c|}{ Eigenvalue of the correlation matrix } & \multicolumn{2}{|c|}{ Eigenvectors of the first component } \\
\hline $\begin{array}{c}\text { Component } \\
\text { no. }\end{array}$ & Eigenvalue & Difference & $\begin{array}{l}\text { Cumulative } \\
\text { percentage of } \\
\text { total variance }\end{array}$ & Variables & Eigenvector \\
\hline 1 & 2.0860 & 1.186 & 0.695 & Compliance with insolvency law & 0.6724 \\
\hline 2 & 0.8996 & 0.885 & 0.995 & Extensiveness of insolvency law & 0.6797 \\
\hline 3 & 0.0144 & . & 1.000 & Enforceability of insolvency law & 0.2929 \\
\hline
\end{tabular}


Appendix Table A3. Determinants of firm distress: Estimation results of the first stage of a Heckman two-stage probit analysis with sample selection

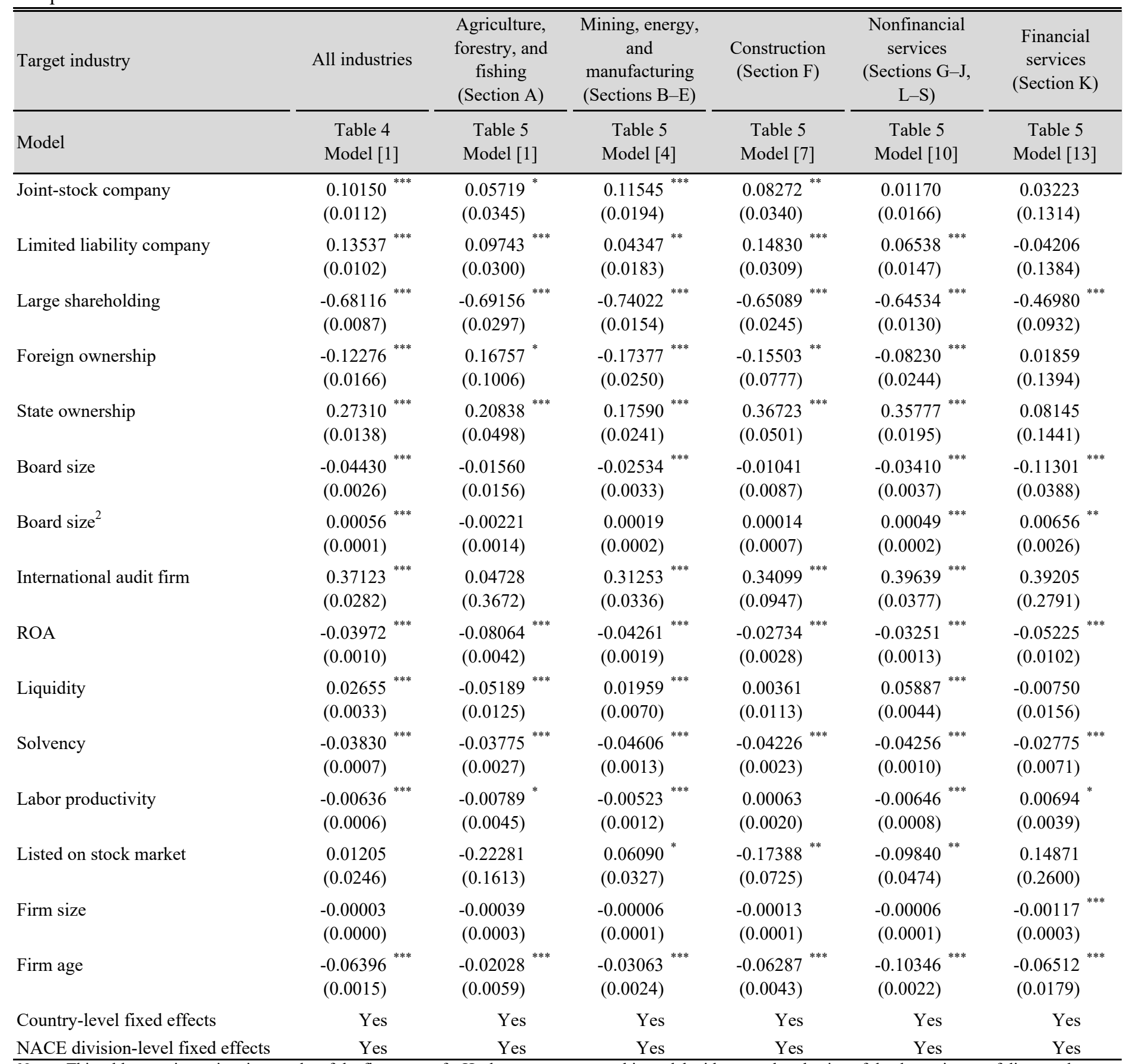

Notes : This table contains estimation results of the first stage of a Heckman two-stage probit model with a sample selection of the determinants of distressed acquisition. The coefficient of a constant term is omitted from the table. The dependent variable is a dummy variable for failed firms. The estimation results of the second stage are reported in Tables 4 and 5. Table 2 provides detailed definitions and descriptive statistics of the independent variables used in the estimation. Figures in parentheses are robust standard errors. ${ }^{* *},{ }^{* *}$, and $*$ denote statistical significance at the $1 \%, 5 \%$, and $10 \%$ levels, respectively. 
Appendix Table A4. Determinants of distressed acquisition: Robustness check estimation of alternative models

\begin{tabular}{|c|c|c|c|c|c|c|c|c|c|}
\hline \multirow{2}{*}{ Model } & \multirow{2}{*}{$\begin{array}{c}\begin{array}{c}\text { Model with } \\
\text { county fixed } \\
\text { effects }\end{array} \\
{[1]}\end{array}$} & \multirow{2}{*}{$\begin{array}{c}\begin{array}{c}\text { Standard errors } \\
\text { clustered by } \\
\text { country }\end{array} \\
{[2]}\end{array}$} & \multirow{2}{*}{$\begin{array}{c}\begin{array}{c}\text { Standard errors } \\
\text { clustered by } \\
\text { industry }\end{array} \\
{[3]}\end{array}$} & \multicolumn{3}{|c|}{$\begin{array}{l}\text { Model with alternative firm-specific variables with } \\
\text { focus on the effects of assets and liabilities }\end{array}$} & \multicolumn{3}{|c|}{ Model with an alternative country-level variable } \\
\hline & & & & [4] & [5] & [6] & [7] & [8] & [9] \\
\hline \multicolumn{10}{|l|}{ Firm-specific variables } \\
\hline Joint-stock company & $\begin{array}{l}-0.16237^{* * *} \\
(0.0174)\end{array}$ & $\begin{array}{l}-0.18106^{* * *} \\
(0.0365)\end{array}$ & $\begin{array}{l}-0.19538^{* * *} \\
(0.0465)\end{array}$ & $\begin{array}{l}-0.06141^{* * *} \\
(0.0069)\end{array}$ & $\begin{array}{l}-0.03109^{* * *} \\
(0.0072)\end{array}$ & $\begin{array}{l}-0.04755^{* * *} \\
(0.0072)\end{array}$ & $\begin{array}{r}-0.01953 \\
(0.0132)\end{array}$ & $\begin{array}{l}-0.08165^{* * *} \\
(0.0131)\end{array}$ & $\begin{array}{l}-0.02577^{* *} \\
(0.0126)\end{array}$ \\
\hline Limited liability company & $\begin{array}{l}-0.07609^{* * *} \\
(0.0163)^{*}\end{array}$ & $\begin{array}{l}-0.11594 \\
(0.1147)\end{array}$ & $\begin{array}{l}-0.157677^{* *} \\
(0.0627)\end{array}$ & $\begin{array}{l}-0.04338^{* * *} \\
(0.0065)\end{array}$ & $\begin{array}{l}-0.02041^{* * *} \\
(0.0068)\end{array}$ & $\begin{array}{r}-0.00690 \\
(0.0068)\end{array}$ & $\begin{array}{l}-0.081677^{* * *} \\
(0.0112)\end{array}$ & $\begin{array}{l}-0.052011^{* * *} \\
(0.0110)\end{array}$ & $\begin{array}{l}-0.095700^{* * *} \\
(0.0107)\end{array}$ \\
\hline Large shareholding & $\begin{array}{l}0.70767^{* * *} \\
(0.0164)\end{array}$ & $\begin{array}{l}0.70377^{* *} \\
(0.3124)\end{array}$ & $\begin{array}{l}0.69435^{* * *} \\
(0.0376)\end{array}$ & $\begin{array}{l}0.13735^{* * *} \\
(0.0054)\end{array}$ & $\begin{array}{c}0.00478 \\
(0.0056)\end{array}$ & $\begin{array}{l}0.02041^{* * *} \\
(0.0057)\end{array}$ & $\begin{array}{l}0.12991^{* * *} \\
(0.0108)\end{array}$ & $\begin{array}{l}0.16287^{* * *} \\
(0.0103)^{*}\end{array}$ & $\begin{array}{l}0.18213^{* * *} \\
(0.0102)\end{array}$ \\
\hline Foreign ownership & $\begin{array}{l}0.21535^{* * *} \\
(0.0283)\end{array}$ & $\begin{array}{l}0.27247^{* * *} \\
(0.0786)\end{array}$ & $\begin{array}{l}0.28243^{* * *} \\
(0.0284)\end{array}$ & $\begin{array}{l}0.052488^{* * *} \\
(0.0130)\end{array}$ & $\begin{array}{l}0.07638^{* * *} \\
(0.0135)\end{array}$ & $\begin{array}{l}0.062466^{* * *} \\
(0.0136)\end{array}$ & $\begin{array}{l}0.03760 \\
(0.0229)\end{array}$ & $\begin{array}{l}0.05114^{* *} \\
(0.0219)\end{array}$ & $\begin{array}{r}0.00159 \\
(0.0211)\end{array}$ \\
\hline State ownership & $\begin{array}{l}0.01866 \\
(0.0255)\end{array}$ & $\begin{array}{l}0.03253 \\
(0.1473)\end{array}$ & $\begin{array}{l}0.05365 \\
(0.0603)\end{array}$ & $\begin{array}{l}0.04104^{* * *} \\
(0.0110)\end{array}$ & $\begin{array}{l}0.05457^{* * *} \\
(0.0114)\end{array}$ & $\begin{array}{l}0.06286^{* * *} \\
(0.0115)\end{array}$ & $\begin{array}{l}0.406022^{* * *} \\
(0.0181)\end{array}$ & $\begin{array}{l}0.33746^{* * *} \\
(0.0175)\end{array}$ & $\begin{array}{l}0.36931^{* * *} \\
(0.0170)\end{array}$ \\
\hline ROA & $\begin{array}{l}0.02962^{* * *} \\
(0.0018)\end{array}$ & $\begin{array}{l}0.02950^{* * *} \\
(0.0057)\end{array}$ & $\begin{array}{l}0.03099^{* * *} \\
(0.0039)\end{array}$ & & & & $\begin{array}{l}0.02207^{* * *} \\
(0.0013)\end{array}$ & $\begin{array}{l}0.02269^{* * *} \\
(0.0012)\end{array}$ & $\begin{array}{l}0.02517^{* * *} \\
(0.0012)\end{array}$ \\
\hline Liquidity & $\begin{array}{l}0.01890^{* * *} \\
(0.0052)\end{array}$ & $\begin{array}{l}0.00528 \\
(0.0072)\end{array}$ & $\begin{array}{r}0.02043 \\
(0.0155)\end{array}$ & & & & $\begin{array}{l}0.02703^{* * *} \\
(0.0044)\end{array}$ & $\begin{array}{l}0.02754^{* * *} \\
(0.0042)\end{array}$ & $\begin{array}{l}0.02558^{* * *} \\
(0.0042)\end{array}$ \\
\hline Solvency & $\begin{array}{l}0.02326^{* * *} \\
(0.0016)\end{array}$ & $\begin{array}{l}0.03252^{* * *} \\
(0.0067)\end{array}$ & $\begin{array}{l}0.02685^{* * *} \\
(0.0048)\end{array}$ & & & & $\begin{array}{l}0.00419^{* * *} \\
(0.0010)\end{array}$ & $\begin{array}{l}0.00475^{* * *} \\
(0.0010)\end{array}$ & $\begin{array}{l}0.00437^{* * *} \\
(0.0009)\end{array}$ \\
\hline Labor productivity & $\begin{array}{l}0.00688^{* * *} \\
(0.0009)\end{array}$ & $\begin{array}{l}0.00835^{*} \\
(0.0043)\end{array}$ & $\begin{array}{l}0.00594^{* * *} \\
(0.0023)\end{array}$ & & & & $\begin{array}{l}0.00492^{* * *} \\
(0.0007)\end{array}$ & $\begin{array}{r}0.00006 \\
(0.0007)\end{array}$ & $\begin{array}{l}0.002611^{* * *} \\
(0.0007)\end{array}$ \\
\hline Listed on stock market & $\begin{array}{l}-0.37695^{* * *} \\
(0.0624)\end{array}$ & $\begin{array}{l}-0.14081 \\
(0.1946)\end{array}$ & $\begin{array}{l}-0.17731^{* * *} \\
(0.0618)\end{array}$ & & & & $\begin{array}{l}-0.51716^{* * *} \\
(0.0530)\end{array}$ & $\begin{array}{l}-0.62930^{* * *} \\
(0.0521)\end{array}$ & $\begin{array}{l}-0.548144^{* * *} \\
(0.0519)\end{array}$ \\
\hline Firm size & $\begin{array}{l}0.00053^{* * *} \\
(0.0001)\end{array}$ & $\begin{array}{l}0.00047 \\
(0.0007)\end{array}$ & $\begin{array}{l}0.00053^{* * *} \\
(0.0001)\end{array}$ & $\begin{array}{l}0.00022^{* * *} \\
(0.0000)\end{array}$ & $\begin{array}{l}0.00026^{* * *} \\
(0.0000)\end{array}$ & $\begin{array}{l}0.00026^{* * *} \\
(0.0000)\end{array}$ & $\begin{array}{l}0.00012^{*} \\
(0.0001)\end{array}$ & $\begin{array}{l}0.00017^{* * *} \\
(0.00006)\end{array}$ & $\begin{array}{r}0.00008 \\
(0.00006)\end{array}$ \\
\hline Firm age & $\begin{array}{c}-0.00274 \\
(0.0046)\end{array}$ & $\begin{array}{l}-0.02936^{*} \\
(0.0167)\end{array}$ & $\begin{array}{l}-0.02013^{* * *} \\
(0.0067)\end{array}$ & $\begin{array}{l}-0.01396^{* * *} \\
(0.0009)\end{array}$ & $\begin{array}{l}-0.01669^{* * *} \\
(0.0010)\end{array}$ & $\begin{array}{l}-0.01902^{* * *} \\
(0.0010)\end{array}$ & $\begin{array}{l}-0.08146^{* * *} \\
(0.0020)\end{array}$ & $\begin{array}{l}-0.06708^{* * *} \\
(0.0020)\end{array}$ & $\begin{array}{l}-0.07340 \text { *** } \\
(0.0019)\end{array}$ \\
\hline \multicolumn{10}{|l|}{ Alternative firm-specific variables } \\
\hline Intangible assets/total assets & & & & $\begin{array}{l}-0.084733^{* *} \\
(0.0333)\end{array}$ & $\begin{array}{l}0.06983^{* *} \\
(0.0342)\end{array}$ & $\begin{array}{c}-0.02975 \\
(0.0345)\end{array}$ & & & \\
\hline Fixed assets/total assets & & & & $\begin{array}{c}0.00721 \\
(0.0048)\end{array}$ & $\begin{array}{l}0.03729^{* * *} \\
(0.0049)\end{array}$ & $\begin{array}{l}0.03117^{* * *} \\
(0.0049)\end{array}$ & & & \\
\hline Long-term liabilities/total liabilities & & & & $\begin{array}{l}-0.02755^{* * *} \\
(0.0037)\end{array}$ & $\begin{array}{l}-0.01904^{* * *} \\
(0.0038)\end{array}$ & $\begin{array}{l}-0.02852^{* * *} \\
(0.0038)\end{array}$ & & & \\
\hline Total debts/total assets & & & & $\begin{array}{l}0.19505 \\
(0.1624)\end{array}$ & $\begin{array}{r}0.07484 \\
(0.1644)\end{array}$ & $\begin{array}{c}0.10995 \\
(0.1661)\end{array}$ & & & \\
\hline \multicolumn{10}{|l|}{ Institutional variables } \\
\hline Comprehensive insolvency law index & & $\begin{array}{l}-0.28750^{* * *} \\
(0.0772)\end{array}$ & $\begin{array}{l}-0.309677^{* * *} \\
(0.0322)\end{array}$ & $\begin{array}{l}-0.08610^{* * *} \\
(0.0016)\end{array}$ & & & & & \\
\hline Corruption control & & & & & $\begin{array}{l}-0.09099^{* * * *} \\
(0.0029)\end{array}$ & & & & \\
\hline Banking reform & & & & & & $\begin{array}{l}-0.05277^{* * *} \\
(0.0033)\end{array}$ & & & \\
\hline \multicolumn{10}{|l|}{ Alternative country-level variables } \\
\hline Economic growth & & & & & & & $\begin{array}{l}0.01878 \text { * } \\
(0.0098)\end{array}$ & & \\
\hline Inflation & & & & & & & & $\begin{array}{l}0.09117^{*} \\
(0.0496)\end{array}$ & \\
\hline Financial depth & & & & & & & & & $\begin{array}{l}-0.162511^{* *} \\
(0.0754)\end{array}$ \\
\hline NACE division-level fixed effects & Yes & Yes & No & Yes & Yes & Yes & Yes & Yes & Yes \\
\hline $\mathrm{N}$ & 211638 & 211638 & 211638 & 169378 & 169378 & 169378 & 211638 & 211638 & 211638 \\
\hline Censored observations & 124460 & 124460 & 124460 & 118696 & 118696 & 118696 & 124460 & 124460 & 124460 \\
\hline Uncensored observations & 87178 & 87178 & 87178 & 50682 & 50682 & 50682 & 87178 & 87178 & 87178 \\
\hline Log likelihood & -165493.700 & -166966.400 & -169034.200 & -101993.200 & -103963.600 & -103749.500 & -170527.800 & -169930.700 & -170274.000 \\
\hline Wald test $\left(\chi^{2}\right)$ & $17718.85^{* * *}$ & $\mathrm{n} / \mathrm{a}$ & $\mathrm{n} / \mathrm{a}$ & $4360.07^{* * *}$ & $2451.06^{* * *}$ & $1708.46^{* * *}$ & $4681.89^{* * *}$ & $6279.99^{* * *}$ & $6034.26^{* * *}$ \\
\hline$\rho$ & -0.706 & -0.903 & -0.846 & 0.264 & 0.384 & 0.249 & 0.881 & 0.940 & 0.966 \\
\hline LR test $\left(\chi^{2}\right)$ & $121.44^{* * *}$ & $5.16^{* *}$ & $21.93^{* * *}$ & $237.01^{* * *}$ & $790.69^{* * *}$ & $216.01^{* * *}$ & $1868.49^{* * *}$ & $2875.57^{* * *}$ & $2063.31^{* * *}$ \\
\hline
\end{tabular}


Appendix Table A5. Determinants of distressed acquisition: Robustness check estimation by country groups

\begin{tabular}{|c|c|c|c|c|c|c|c|c|c|}
\hline \multirow{2}{*}{$\begin{array}{l}\text { Target country group } \\
\text { Model }\end{array}$} & \multicolumn{3}{|c|}{ Without Russia } & \multicolumn{3}{|c|}{ EU member states } & \multicolumn{3}{|c|}{$\begin{array}{c}\text { EU member states } \\
\text { excluding Bulgaria, Croatia, and Romania }\end{array}$} \\
\hline & [1] & [2] & [3] & [4] & [5] & [6] & [7] & [8] & [9] \\
\hline \multicolumn{10}{|l|}{ Firm-specific variables } \\
\hline Joint-stock company & $\begin{array}{l}0.01301 \\
(0.0159)\end{array}$ & $\begin{array}{l}0.06365^{* * *} \\
(0.0078)\end{array}$ & $\begin{array}{l}0.10159^{* * *} \\
(0.0078)\end{array}$ & $\begin{array}{l}0.44983^{* * *} \\
(0.0304)\end{array}$ & $\begin{array}{l}0.14735^{* * *} \\
(0.0342)\end{array}$ & $\begin{array}{l}0.36053^{* * *} \\
(0.0310)\end{array}$ & $\begin{array}{l}-0.10788^{* * *} \\
(0.0368)\end{array}$ & $\begin{array}{r}-0.03782 \\
(0.0377)\end{array}$ & $\begin{aligned}-0.03991 \\
(0.0414)\end{aligned}$ \\
\hline Limited liability company & $\begin{array}{l}0.16385^{* * *} \\
(0.0114)\end{array}$ & $\begin{array}{l}0.17857^{* * *} \\
(0.0058)\end{array}$ & $\begin{array}{l}0.18870 * * * \\
(0.0060)\end{array}$ & $\begin{array}{l}0.349211^{* * *} \\
(0.0228)\end{array}$ & $\begin{array}{l}0.08353^{* * *} \\
(0.0236)\end{array}$ & $\begin{array}{l}0.24553^{* * *} \\
(0.0251)\end{array}$ & $\begin{array}{l}-0.13306^{* * *} \\
(0.0330)\end{array}$ & $\begin{array}{l}-0.08129 * * \\
(0.0365)\end{array}$ & $\begin{array}{l}-0.13585^{* * *} \\
(0.0368)\end{array}$ \\
\hline Large shareholding & $\begin{array}{l}0.38778^{* * *} \\
(0.0109)\end{array}$ & $\begin{array}{l}0.08345^{* * *} \\
(0.0065)\end{array}$ & $\begin{array}{l}0.020144^{* *} \\
(0.0081)\end{array}$ & $\begin{array}{l}0.62188^{* * *} \\
(0.0197)\end{array}$ & $\begin{array}{l}0.61367^{* * *} \\
(0.0203)\end{array}$ & $\begin{array}{l}0.64911^{* * *} \\
(0.0185)\end{array}$ & $\begin{array}{l}0.51226^{* * *} \\
(0.0241)\end{array}$ & $\begin{array}{l}0.54333^{* * *} \\
(0.0238)\end{array}$ & $\begin{array}{l}0.52115^{* * *} \\
(0.0264)\end{array}$ \\
\hline Foreign ownership & $\begin{array}{l}0.14664^{* * *} \\
(0.0199)\end{array}$ & $\begin{array}{l}0.07929^{* * *} \\
(0.0109)\end{array}$ & $\begin{array}{l}0.02513 \text { ** } \\
(0.0111)\end{array}$ & $\begin{array}{l}0.17958^{* * *} \\
(0.0283)\end{array}$ & $\begin{array}{l}0.18457^{* * *} \\
(0.0296)\end{array}$ & $\begin{array}{l}0.17848^{* * *} \\
(0.0268)\end{array}$ & $\begin{array}{l}0.18844^{* * *} \\
(0.0363)\end{array}$ & $\begin{array}{l}0.21048 * * * \\
(0.0364)\end{array}$ & $\begin{array}{l}0.24670 \\
(0.0402)\end{array}$ \\
\hline State ownership & $\begin{array}{l}0.13057^{* * *} \\
(0.0234)\end{array}$ & $\begin{array}{l}0.06797^{* * *} \\
(0.0118)\end{array}$ & $\begin{array}{l}0.18719^{* * *} \\
(0.0122)\end{array}$ & $\begin{array}{l}0.07745 \\
(0.0490)\end{array}$ & $\begin{array}{l}0.09014{ }^{*} \\
(0.0511)\end{array}$ & $\begin{array}{l}0.06016 \\
(0.0472)\end{array}$ & $\begin{array}{l}0.18352^{* * *} \\
(0.0581)\end{array}$ & $\begin{array}{l}0.25557^{* * *} \\
(0.0586)\end{array}$ & $\begin{array}{l}0.222711^{* * *} \\
(0.0613)\end{array}$ \\
\hline ROA & $\begin{array}{l}0.03545^{* * *} \\
(0.0015)\end{array}$ & $\begin{array}{l}0.01169^{* * *} \\
(0.0009)\end{array}$ & $\begin{array}{l}0.00070 \\
(0.0009)\end{array}$ & $\begin{array}{l}0.023211^{* * *} \\
(0.0027)\end{array}$ & $\begin{array}{l}0.02222^{* * *} \\
(0.0028)\end{array}$ & $\begin{array}{l}0.02508^{* * *} \\
(0.0026)\end{array}$ & $\begin{array}{l}0.03277^{* * *} \\
(0.0036)\end{array}$ & $\begin{array}{l}0.03018^{* * *} \\
(0.0036)\end{array}$ & $\begin{array}{l}0.03523^{* * *} \\
(0.0039)\end{array}$ \\
\hline Liquidity & $\begin{array}{l}0.025411^{* * *} \\
(0.0057)\end{array}$ & $\begin{array}{l}0.01046^{* * *} \\
(0.0029)\end{array}$ & $\begin{array}{l}0.01177^{* * *} \\
(0.0029)\end{array}$ & $\begin{array}{l}0.05130^{* * *} \\
(0.0111)\end{array}$ & $\begin{array}{l}0.064744^{* * *} \\
(0.0116)\end{array}$ & $\begin{array}{l}0.05023 \\
(0.0104)\end{array}$ & $\begin{array}{l}0.07307^{* * *} \\
(0.0146)\end{array}$ & $\begin{array}{l}0.07986 * * * \\
(0.0146)\end{array}$ & $\begin{array}{l}0.084288^{* * *} \\
(0.0162)\end{array}$ \\
\hline Solvency & $\begin{array}{l}0.03707^{* * *} \\
(0.0011)\end{array}$ & $\begin{array}{l}0.01288^{* * *} \\
(0.0007)\end{array}$ & $\begin{array}{l}0.00906^{* * *} \\
(0.0008)\end{array}$ & $\begin{array}{l}0.04298^{* * *} \\
(0.0021)\end{array}$ & $\begin{array}{l}0.04033^{* * *} \\
(0.0022)\end{array}$ & $\begin{array}{l}0.042144^{* * *} \\
(0.0020)\end{array}$ & $\begin{array}{l}0.03988^{* * *} \\
(0.0027)\end{array}$ & $\begin{array}{l}0.041444^{* * *} \\
(0.0027)\end{array}$ & $\begin{array}{l}0.03773^{\text {*** }} \\
(0.0030)\end{array}$ \\
\hline Labor productivity & $\begin{array}{l}0.00430 * * * \\
(0.0008)\end{array}$ & $\begin{array}{l}0.00241^{* * *} \\
(0.0004)\end{array}$ & $\begin{array}{l}0.00245^{* * *} \\
(0.0004)\end{array}$ & $\begin{array}{l}0.00716^{* * *} \\
(0.0012)\end{array}$ & $\begin{array}{l}0.00807^{* * *} \\
(0.0013)\end{array}$ & $\begin{array}{l}0.005111^{* * *} \\
(0.0013)\end{array}$ & $\begin{array}{r}-0.00047 \\
(0.0016)\end{array}$ & $\begin{array}{l}0.00173 \\
(0.0017)\end{array}$ & $\begin{array}{l}0.00052 \\
(0.0018)\end{array}$ \\
\hline Listed on stock market & $\begin{array}{l}-0.14995^{* * *} \\
(0.0351)\end{array}$ & $\begin{array}{l}-0.18785^{* * *} \\
(0.0156)\end{array}$ & $\begin{array}{l}-0.30489^{* * *} \\
(0.0159)\end{array}$ & $\begin{array}{l}-0.35350 * * * \\
(0.0693)\end{array}$ & $\begin{array}{l}-0.28240^{* * *} \\
(0.0721)\end{array}$ & $\begin{array}{l}-0.319466^{* * *} \\
(0.0646)\end{array}$ & $\begin{array}{c}-0.23996 \\
(0.2242)\end{array}$ & $\begin{array}{r}-0.29596 \\
(0.2264)\end{array}$ & $\begin{array}{c}-0.51409^{*} \\
(0.2630)\end{array}$ \\
\hline Firm size & $\begin{array}{l}0.00007 \\
(0.0001)\end{array}$ & $\begin{array}{l}0.00010 \text { *** } \\
(0.00004)\end{array}$ & $\begin{array}{r}-0.00005 \\
(0.00004)\end{array}$ & $\begin{array}{l}0.00129^{* * *} \\
(0.0001)\end{array}$ & $\begin{array}{l}0.00147^{* * *} \\
(0.0001)\end{array}$ & $\begin{array}{l}0.00115^{* * * *} \\
(0.0001)\end{array}$ & $\begin{array}{l}0.00142^{* * *} \\
(0.0002)\end{array}$ & $\begin{array}{l}0.00133^{* * *} \\
(0.0002)\end{array}$ & $\begin{array}{l}0.00134^{* * *} \\
(0.0002)\end{array}$ \\
\hline Firm age & $\begin{array}{l}0.01898^{* * *} \\
(0.0021)\end{array}$ & $\begin{array}{l}0.00081 \\
(0.0011)\end{array}$ & $\begin{array}{l}0.01132^{* * *} \\
(0.0011)\end{array}$ & $\begin{array}{l}0.03889^{* * *} \\
(0.0034)\end{array}$ & $\begin{array}{l}0.03336^{* * *} \\
(0.0035)\end{array}$ & $\begin{array}{l}0.03799^{* * *} \\
(0.0032)\end{array}$ & $\begin{array}{l}0.012811^{* * *} \\
(0.0042)\end{array}$ & $\begin{array}{l}0.02078^{* * *} \\
(0.0042)\end{array}$ & $\begin{array}{l}0.01055^{\text {** }} \\
(0.0046)\end{array}$ \\
\hline \multicolumn{10}{|l|}{ Institutional variables } \\
\hline Comprehensive insolvency law index & $\begin{array}{l}-0.13426^{* * *} \\
(0.0032)\end{array}$ & & & $\begin{array}{l}-0.19724 * * \\
(0.0795)\end{array}$ & & & $\begin{array}{l}-0.129244^{* * *} \\
(0.0099)\end{array}$ & & \\
\hline Corruption control & & $\begin{array}{l}-0.187233^{* * *} \\
(0.0026)\end{array}$ & & & $\begin{array}{l}-0.36769^{* * *} \\
(0.0254)\end{array}$ & & & $\begin{array}{l}-0.21250 \text { *** } \\
(0.0427)\end{array}$ & \\
\hline Banking reform & & & $\begin{array}{l}-0.17344^{* * *} \\
(0.0042)\end{array}$ & & & $\begin{array}{l}-0.06757^{* * *} \\
(0.0189)\end{array}$ & & & $\begin{array}{l}-0.963388^{* * *} \\
(0.0622)\end{array}$ \\
\hline NACE division-level fixed effects & Yes & Yes & Yes & Yes & Yes & Yes & Yes & Yes & Yes \\
\hline $\mathrm{N}$ & 105925 & 105925 & 105925 & 61803 & 61803 & 61803 & 36455 & 36455 & 36455 \\
\hline Censored observations & 73788 & 73788 & 73788 & 45314 & 45314 & 45314 & 28347 & 28347 & 28347 \\
\hline Uncensored observations & 32137 & 32137 & 32137 & 16489 & 16489 & 16489 & 8108 & 8108 & 8108 \\
\hline Log likelihood & -74106.320 & -75831.790 & -77703.366 & -36230.620 & -36101.860 & -36227.970 & -20269.980 & -20363.720 & -20194.380 \\
\hline Wald test $\left(\chi^{2}\right)$ & $7244.27^{* * *}$ & $8302.43^{* * *}$ & $4750.63^{* * *}$ & $4380.04^{* * *}$ & $4253.54^{* * *}$ & $4783.84^{* * *}$ & $2032.88^{* * *}$ & $1941.59^{* * *}$ & $1844.05^{* * *}$ \\
\hline$\rho$ & -0.995 & -0.566 & -0.998 & -0.946 & -0.935 & -0.965 & -0.967 & -0.967 & -0.940 \\
\hline LR test $\left(\chi^{2}\right)$ & $2161.84^{* * *}$ & $183.33^{* * *}$ & $5400.22^{* * *}$ & $528.38^{* * *}$ & $481.93^{* * *}$ & $458.04^{* * *}$ & $457.11^{* * * *}$ & $258.31^{* * *}$ & $276.69^{* * *}$ \\
\hline
\end{tabular}

Notes : This table contains estimation results of a Heckman probit model with a sample selection of the determinants of distressed acquisition. The coefficient of a constant term is omitted from the table. Table 2 provides detailed definitions and descriptive statistics of the independent variables used in the estimation. Figures in parentheses are robust standard errors. The Wald test examines the null hypothesis that all coefficients are zero. The LR test of the independence of equations examines the null hypothesis that $\rho=0 . * *, * *$, and $*$ denote statistical significance at the $1 \%, 5 \%$, and $10 \%$ levels, respectively. 